\title{
İş Tatmini ve Kaygı Düzeyinin İşten Ayrılma Niyeti Üzerine Etkisi: Banka Çalışanları Üzerine Ampirik Bir Araştırma
}

\begin{abstract}
Özlem Karadağ Ak* Ahmet Diken ${ }^{* *}$

Öz

Çalışmanın amacı, işten ayrılma niyetinin, iş tatmini ve kaygı düzeyi değişkenleri üzerinden ne derece etkilendiğinin ölçülmesidir. Araştırmada veri toplama yöntemi olarak anket tekniğinden yararlanılmışır. Araştırma, Konya'da faaliyet gösteren özel ve kamu sektöründe yer alan mevduat ve katılım bankalarının 413 çalışanı üzerinde gerçekleştirilmiş̧tir. Verilerin analizi aşamasında, katılımcıların ölçeklerden aldıkları puanların demografik değişkenlere göre değişip değişmediğini tespit etmek amacıyla bağımsız gruplar t testi ve çok değişkenli varyans analizi (MANOVA) ve onu takip eden tek yönlü varyans analizi (ANOVA) yapılmıştır. Değişkenler arasındaki ilişkiler Pearson korelasyon katsayısı ile hesaplanmıştır. Daha sonra durumluk ve sürekli kaygı ile işten ayrılma niyeti arasındaki ilişkide iş tatmininin aracı rolü bootstrapping yöntemiyle incelenmiştir.Araştırma sonuçlarına göre; durumluk kaygı ve sürekli kaygı iş tatmini ile negatif yönlü orta düzeyde ve işten ayrılma niyeti ile pozitif yönlü orta düzeyde; iş tatmini ise işten ayrılma niyeti ile negatif yönlü orta düzeyde ilişkili olarak bulunmuştur.
\end{abstract}

Anahtar Kelimeler: iş̧ tatmini, Durumluk kaygı, Sürekli kaygı, İşten ayrılma niyeti, Banka çalışanları.

JEL Sınıflandırması: M1, M5.

\section{Abstract - The Effect of Job Satisfaction and Anxiety Level on Turnover Intention: An Ampirical Research on Bank Employees}

The aim of the study is to investigate the extent to which the intention to leave is affected by the variables of job satisfaction and anxiety level. In this research, the questionnaire technique was used as a data gathering method. The research sample was composed of 413 employees of deposit and participation banks that are operating in the public and private sector in Konya. During the analysis phase of the data, independent groups t-test and multivariate analysis of variance (MANOVA) and one-way analysis of variance (ANOVA) were performed to determine whether the scores of the participants varied according to demographic variables. The relations among the variables were calculated by Pearson correlation analysis. Then, the mediating role of job satisfaction in the relationship between trait and state anxiety and intention to leave was examined with the bootstrapping method. State anxiety and trait anxiety was related to negatively and medium level with job satisfaction. State anxiety and trait anxiety was related to positively and medium level with the intention to leave. It was found out that job satisfaction was negatively and medium level associated with the intention to leave.

Keywords: Job satisfaction, State anxiety, Trait anxiety, Turnover intention, Bank employees.

JEL Classification: M1, M5.

\footnotetext{
* Sorumlu yazar, Necmettin Erbakan Üniversitesi, Uygulamalı Bilimler Fakültesi, Bankacılık Bölümü -

E-posta: ozlemkaradagak@gmail.com - ORCID ID: https://orcid.org/0000-0002-3761-081X

** Necmettin Erbakan Üniversitesi, Siyasal Bilgiler Fakültesi, İşletme Bölümü - E-posta: adiken@erbakan.edu.tr ORCID ID: https://orcid.org/0000-0002-6455-9749
}

Makale Gönderim: 30.07.2020

Makale Kabul: 13.10.2020

DOI: 


\section{Giriş}

Son yıllarda yaşanan teknoloji, iletişim ve sosyal ilişkilerdeki değişimler, her alanda olduğu gibi bankacılık sektöründe de doğal ve zorunlu olarak yaşanmaktadır. Bankacılık sektörünün bu değişimlere ayak uydurup kendini yenilemesi ve modernleşmesiyle birlikte hizmet hızını da artıırıp yeni ürünler geliştirerek müşterilerine sunması kaçınılmaz bir hal almıştır. Bu hızlı değişimle birlikte eğitim seviyesi ve farkındalıkları artan müşterilerin, beklentilerinin karşılanması için bankacılık sektörünün rekabet yeteneğini de arttırması gerekmektedir. Bunu sağlamanın yolu ise çalışana hem bireysel hem de işle ilgili yatırım yapmaktır. Müşteri memnuniyeti ve yapılan işin kalitesini artırmak için, çalışanların iş doyumunun ve kurumsal bağlıı̆ının yüksek olması, avantaj sağlamaktadır (Koçak ve Erdoğan, 2011: 260-261). Bu nedenle, bankacılık sektöründe başarılı bir insan kaynakları yönetimi ile çalışanın iş tatmininin sağlanarak ve birçok faktöre bağlı olan kaygılarının azaltılarak bankaların verimliliğine ve kârılı̆̆ına önemli katkı sağlayacağı düşünülmektedir.

Türkiye'de çalışan sirkülasyonunun en çok yaşandığı meslek gruplarını içeren bankacılık sektöründe en alt tabakadan en üst tabakaya kadar birçok çalışanın sıkıkla iş değiştirdiği gözlemlenmiş̧ir. Ülkemizde genç nüfusun, faaliyet gösteren kurum sayısının, bankacılıkla ilgili eğitim veren üniversitelerin fazla olması gibi nedenlerle, sektörde çalışanlar kıt kaynak olmaktan çıkmaktadır. Çalışanların alternatiflerinin fazla olması, kurumların insan kaynakları departmanlarınca da bilinmekte olup, bu durum çalışan değerliliğini düşürmektedir (Kılı̧, 2017: 54).

Çalışmamızda banka çalışanlarının sahip oldukları kaygı düzeyleri ve iş tatmini seviyelerinin, onların işten ayrılma niyetlerini ne derecede etkilediğini ölçmek amaçlanmıştır. Bu amaçla farklı banka türlerindeki çalışanların kamu- özel ve mevduat- katılım bankaları ayrımı da göz önünde bulundurularak gerek iş başındaki kaygılarını ölçmek için durumluk kaygıları gerekse genellikle değişmeyen bir kişilik özelliği olan sürekli kaygı seviyeleri ele alınmış ve iş tatmini seviyeleriyle birlikte işten ayrılma niyetleri ölçülmüştür.

\section{Literatür İncelemesi}

Günümüzde artan rekabet şartlarında işletmelerin devamlılıklarını sağlaması oldukça zorlaşmışır. Böyle bir ortamda işletmelerin devamlııklarını sağlayabilmeleri için çalışanlarına önem vermeleri elbetteki kaçınılmazdır. Kurumların çalışanlarıyla ilişkisi, kuruma karşı sergiledikleri davranışlar daha fazla araştırma konusu yapılmaya başlanmıştır (Yavuz ve Bedük, 2016: 302). 
Işten ayrılma (turnover) kavramı örgütsel davranış alanında en çok araştııılan konulardan biridir. Fakat 1990'ların başından beri işten ayrılma kavramından çok işten ayrılma niyeti (turnover intention) kavramılla ilgili çalışmalara ağırlık verildiği görülmektedir. Bunun sebebi ise işten ayrımanın gerçekleşmiş; işten ayrılma niyetinin ise gelecekte yapılması olası bir ihtimali temsil ediyor olmasıdır. İşten ayrılma niyetiyle ilgili yapılan çalışmaların sonuçları kuruluşlara, henüz çalışan işi bırakmadan önce önlem almaları konusunda yardımcı olur. İşten ayrıma niyeti kavramında yer alan "niyet" çalışanın kendisi ve bazı hareketleri arasındaki ilişkiyi kapsayan ve çalışanın bir davranış göstereceğine dair objektif olmayan olasıı̆̆ı ifade etmektedir (Şimşek ve Kara, 2017: 88).

İşten ayrılma niyeti, bireysel seçim davranışıdır (Mobley vd., 1979: 493). Kişiler işten ayrılmaya niyet ettiklerinde birçok unsuru gerekçeleriyle analiz ederler. Bu gerekçelerin objektif bir biçimde tespit edilmesi ise örgüt ve özellikle de yöneticiler için vazgeçilmez bir ihtiyaçtır. Çünkü işten ayrılma niyeti, kişilerin çalıştıları kuruluşu bırakmaları için yaptıkları planın ana unsurunu oluşturmaktadır (Altay, 2018: 97).

Modern organizasyonların 21. yüzyılın başlarında benzeri görülmemiş çalışan zorlukları ile karşı karşıya kalmış olmaları muhtemeldir. Kalifiye çalışan alımı kadar bilgili çalışanları elde tutmak da aynı derecede önemli olacaktır. Mevcut işgücünde gönüllü işten ayrılmaları proaktif olarak azaltmanın yollarını bulabilen kuruluşlar bu zorlukların üstesinden gelmede çok daha hazırlıklı olacaktır (Dawley vd., 2010: 238).

Tett ve Meyer (1993) işten ayrılma niyetini, alternatif iş arama niyetinde olma ve bırakma düşüncelerini de içeren, örgütten ayrılmak için bilinçli ve kasıtlı bir isteklilik olarak kabul etmiş̧ir (Tett ve Meyer, 1993: 262).

İş tatmini ile ilgili yapılan araştırmalar 19.yy'ın başlarında artmaya başlamışır. Araşıımacılar, çalışanların tutum ve davranışlarıyla ilgili birçok çalışma yaparak iş tatmininin kapsamını tespit etmeye çalışmışlardır. Günümüzün yönetim anlayışı, çaıışma hayatının vazgeçilmezi olan insanı en verimli ve etkin bir şekilde kullanmayı işletmeler açısından zorunlu kılmaktadır. Gereken özelliklere sahip olan insanların işe alınması ve tatmin edilerek verimli olmalarının sağlanması, yöneticilerin temel amaçlarından biri olmuştur (Güney, 2007: 37-38).

İş tatmini, çalışanın işinden sağladığı maddi çıkarlar ile birlikte çalışmaktan keyif aldığı iş arkadaşlarıyla ortaya bir yapıt meydana getirmenin sağladığı mutluluktur. Çalışan işin sonucunda meydana getirdiği yapıtı somut olarak görebiliyorsa, bunun sonucunda duyacağı gurur, kendisi için büyük bir tatmin kaynağı olacaktır (Eren, 2001: 202).

Ö. K. Ak, A. Diken, “iş Tatmini ve Kaygı Düzeyinin İşten Ayrıma Niyeti Üzerine Etkisi: Banka Çalışanları Üzerine Ampirik Bir Araştırma”, BDDK Bankacllık ve Finansal Piyasalar Dergisi, 14, (2), 2020, 175-204 
Duygular, insanoğluna hayatta kalma, tehlikelerden korunma ve seçenekler içinde tercihler oluşturmada kılavuzluk yapan, doğuştan bahşedilmiş mükemmel yaradıışın önemli bir parçasıdır. Kaygı en çok yaşanan duygulardan biridir. Normal kaygı, içsel ve dışsal değişkenler paralelinde oluşan ve şiddeti değişen, bir nevi uyarı sistemi gibi tedbirli olmayı sağlayan bir araçtır. İnsana ortamda ya da iç dünyasında tedbir alması gereken değişimler olduğunu haber verir. Ayrıca bedeni savaş ya da kaç pozisyonuna geçirerek gelecek somut tehlikeler karşısında hayatta kalmak için kaçma ya da savaşma tepkisini vakit kaybetmeden vermesini hedefler (Işık, 1996: 31;Türkçapar, 2019: 80-110). Günlük hayatımızda tekin bulunmayan bir mahallede yürürken hissedilen kaygı, kalbimizi daha hızı attırır, nefesimiz hızlanır, göz bebeklerimiz büyür ve adımlarımız hızlanır. Bu mahalledeki yürüyüş mesafesi kısa olsa bile harcanan enerjinin fazlalığı ve kasların gerginleşmesi gibi bedendeki alarm sisteminin çalışmasına bağlı değişiklikler kişiyi uzun bir yol yürümüşçesine yorgun hissettirir. Somut tehlikeler veya riskler karşısında hissedilen kaygı işlevseldir. Ancak uyaranla uyumlu olmayan kaygı tersi şekilde işlev bozucudur. Örneğin ertesi gün sınav olduğunda hissedilen normal düzeydeki bir kaygı bizi ders çalışmaya iterken kaygının fazla olması konsantrasyonumuzu bozacağından öğrenmemizi bile olumsuz etkileyebilir. Ya da ortamda bir tehlike yok iken zihinsel süreçler sonucunda oluşan kaygı da gereksiz yere alarm sisteminin çalışmasına neden olacağından kişinin yorgun hissetmesine ve işlev düşüklüğüne neden olabilir. Bir de bu kaygı yüksekliği süreklilik arz eder ise yukarıda tanımlandığı gibi bedensel birçok belirtiye yol açıp kişide çeşitli hastalıkların oluşmasını kolaylaştırabilir (Noyes ve Hoehn-Saric, 1998: 5; Işık, 1996: 151). Buradaki ana sorun kaygının nedenine bakmaksızın beynin her kaygıda vücudu ya hep ya hiç ilkesi ile savaşmaya ve kaçmaya hazırlamasıdır.

Iş yerindeki nedenler ya da hayata dair başka etkenlerle oluşmuş durumluluk kaygısı ya da daha çok kişinin kişilik özelliklerinin bir parçası olan, içinde bulunduğu durumları kolaylıkla kaygı verici olarak algılamasına yol açabilen sürekli kaygısının düzeyinin yüksekliği ve sürekliliği, yukarıda sayılan nedenlerden dolayı bireylerde işlevsellikte düşmeyle sonuçlanabilecek olumsuz değişimlere yol açabilir. Kaygı varoluş nedeni açısından canlıyı kaçmaya veya savaşmaya hazırladığından oluştuğu ortamlardan uzaklaşma güdüsüne neden olacağı için bu işten ayrılma niyetini -belki de bilinçsizce- canlı tutabilir. Ayrıca kişide süreklilik olduğu zaman mutsuzluğu da getireceğinden iş tatminini de düşürebileceği söylenebilir.

Durumluluk kaygı, dışsal ya da içsel bir etken ile ortaya çıkar. Gerçek ya da gerçek olduğu varsayılan/algılanan bir uyaran karşısında kişide geçici bir süreliğine gelişir. Birey için tehlikeli olabilecek koşulların yarattığı korku ve tedirginlik olarak da tanım- 
lanan geçici bu kaygı haline "Durumluk Kaygı" adı verilmektedir. Stresinin varlığı ve yoğunluğuna göre seviyesinde yükselme ve düşme olabilmektedir (Öner ve Le Compte, 1985).

Kaygı bazı kişilerde sürekli olarak yaşanır ve genellikle bu kişiler mutsuzdurlar. Kişinin karşılaştığı durumları yorumlama, değerlendirme biçimi ve gösterilen tutum gibi kişilik yapısına ait özellikler kaygı oluşturmaya yatkınlık gösterebilir. Bu kişilerde kaygı duygusu süreklilik gösterebilir. Dış dünyada var olan somut tehlikelerden oluşmayan bu kaygı türü içten kaynaklanır. Kişi öz değerlerinin tehdit altında olduğunu zannedebilir veya içinde bulunduğu durumları stres verici olarak yorumlayarak bu kaygı duygusunun oluşmasına yol açabilir. Bu kaygı türüne de "Sürekli Kaygı" denir (Öner ve LeCompte, 1985). Sürekli kaygı genellikle değişmeyen bir kişisel özellik olarak tanımlanır (Öner ve LeCompte, 1985: 2).

Yüksek iş tatmini, işten ayrılma oranını tek başına düşürmez ancak yardımcı olur. Öte yandan, ciddi bir iş tatminsizliği varsa, yüksek işten ayrılmaların olması muhtemeldir. Kendilerini başka hiçbir yerde çalışırken göremeyen bazı çalışanlar, bu yüzden ne kadar tatmin olduklarını düşünmeden çalışmaya devam ederler. Diğer bir faktör ise genel ekonomidir. Ekonomideki işler iyi gittiğinde ve işsizlik oranı az olduğunda, tipik olarak işten ayrılmalarda bir artış olacak çünkü insanlar diğer kuruluşlarda daha iyi fırsatlar aramaya başlayacaklar. Başka işletmeler fırsatların daha iyi olacağına inandırırsa, birçok çalışan mevcut işlerinden memnun olsalar bile gitmeye istekli olur. Öte yandan, işler zorlaşır ve küçülürse, birleşme ve satın almalar meydana gelirse, son yıllarda olduğu gibi, memnuniyetsiz çalışanlar gönüllü olarak bulundukları yerde kalacaktır. Her ne kadar kesin bir işten ayrılma, organizasyon için mutlaka faydalı olmasa da, düşük eğitim oranları, önemli eğitim maliyetleri ve deneyimsizliğin sakıncaları ve ayrıca onlarla birlikte kalanların aldıkları zımni bilgilerin kaybı nedeniyle arzu edilebilmektedir (Luthans, 2011: 145).

Kadın ve erkek çalışanlar arasında iş tatmini farklılıklarını ele alan ulusal ve uluslararası yapılmış araştırmaların sonuçları arasında bir tutarlıık yoktur. Hulin ve Smith (1964), 295 erkek ve 164 kadın katııımıyla yaptığı araştırmalarında kadın çalışanların erkek çalışanlara kıyasla işlerinden daha az tatmin oldukları sonucuna varmışlardır ve sonrasında başka çalışma sonuçları da benzer olarak rapor edilmiştir (Hulin ve Smith, 1964; Okpara, 2006; Çarıkçı, 2004; Al- Mashaan, 2003). Iş tatmini ve cinsiyet arasındaki ilişki hakkında yapılan bazı araştırmalarda ise, kadınların erkeklere göre daha yüksek iş tatminine sahip oldukları bulunmuştur (Imran vd., 2010; Eğinli, 2009; Groot vd., 1999; Kaya ve Oğuzöncül, 2016; Lambert vd., 2001).

Ö. K. Ak, A. Diken, “iş Tatmini ve Kaygı Düzeyinin İşten Ayrıma Niyeti Üzerine Etkisi: Banka Çalışanları Üzerine Ampirik Bir Araştırma”, BDDK Bankacilık ve Finansal Piyasalar Dergisi, 14, (2), 2020, 175-204 
Çelen (2015) ve Robie vd. (1998) yapmış oldukları araştırmalarında, görev pozisyonu arttıkça iş tatmininin de artacağını, buna karşııı Akyüz vd. (2011) yaptıkları çalışmada ise çalışanların kurumdaki pozisyonları ile iş tatmin düzeyleri arasında herhangi bir farklıık olmadığını tespit etmiştir.

Byrd ve diğerleri (2000), hapishane çalışanlarında yapılan bir araştırmada kaygının iş stresinin ve işten ayrılma niyetinin bir göstergesi olan iş tatminsizliğinin önemli bir yordayıcısı olduğunu, hapishane çalışanlarından daha yüksek kaygı düzeyine sahip olanların istifaya eğilimli olduğunu belirtmişler ve Jensen ve arkadaşları da başka bir çalışmada bunu destekler tarzda kaygı yüksekliğinin işten ayrılma niyetini artırdığını tanımlamışlardır (Byrd vd., 2000; Jensen vd., 2013).

Yukongdi ve Shrestha (2020)' nın Nepal'daki 282 banka çalışanı arasında, duygusal bağlılık, iş tatmini ve iş stresinin işten ayrılma niyeti üzerine etkilerini inceledikleri çalışmalarında duygusal bağlılık ve iş tatmininin işten ayrılma niyeti üzerine olumsuz bir etkisi olduğunu, iş stresinin ise işten ayrılma niyeti üzerinde olumlu bir etkisinin olduğu sonucuna ulaşmışlardır (Yukongdi ve Shrestha, 2020).

Sopiah ve Sangadji (2020), iş tatmini yoluyla iş stresinin işten ayrılma niyetine etkisini araştırdıkları çalışmalarını 600 kişilik kamu bankası personeline uygulamışlar ve araştırma sonucunda iş stresinin artmasının iş tatminini azalttığını ve işten ayrılma niyetini arttırdığı sonucuna ulaşmışlardır (Sopiah ve Sangadji, 2020).

Akhtar vd. (2018)' nin banka çalışanlarındaki iş stresinin iş tatmini üzerine etkisini araştırdığı çalışmalarında, çalışanların büyük çoğunluğunun iş stresi azalan düzeyinin iş tatminlerini artırdığı sonucuna varmışlardır.

\section{Araştırmanın Konusu}

Bu çalışmada, Konya'daki özel ve kamu sektöründe yer alan mevduat ve katılım bankalarında çalışanların işinden duymuş olduğu tatmin ve kaygı düzeylerinin, işten ayrılma niyetleri üzerine etkisi konu edilmiştir. Aynı zamanda yaş, cinsiyet, medeni durum, kıdem, gelir, çalışılan bölüm, pozisyon, çocuk sayısı, eğitim düzeyi bilgilerini içeren demografik özelliklerin, belirtilen değişkenler üzerindeki etkilerine de yer verilmiştir.

Literatürde bankacılık alanında iş tatmini ve işten ayrılma niyeti ile ilgili çalışmalar olmakla birlikte özellikle kaygının buradaki rolü üzerinde araştırmalar sınırlı düzeydedir. Araştırmanın ülkemizde bankacılık alanında kaygı, işten ayrılma niyeti ve iş tatmininin birlikte değerlendirildiği bilinen ilk araştırma olması nedeniyle elde edilen verilerin sektöre ve literatüre katkı sağlayacağı düşünülmüştür. 
Çalışmada bazı kısıtlar bulunmaktadır. Illk önemli kısıt, bankaların tüm Türkiye'deki çalışanlarına ulaşmak mümkün olmadığı için araştırmanın kapsamına sadece Konya ilinde bulunan bankaların bölge müdürlükleri ve şube çalışanlarının dâhil edilmiş olmasıdır. İkinci kısıtımız ise, anket yöntemi kullanılarak yapılan bu çalışmada verilerin sadece araştırmacılar tarafından toplanmasından dolayı yanlıı̆g neden olmasıdır.

\section{Araştırmanın Amacı ve Hipotezleri}

Araştırmanın amacl; işten ayrılma niyetinin, iş tatmini ve kaygı düzeyi değişkenleri üzerinden ne derece etkilendiğinin ölçülmesidir. Bu bağlamda, araştırma konusu olan çalışanın;

- Demografik özelliklerini belirlemek,

- Iş tatmin seviyelerini belirlemek,

- Kaygı düzeylerini belirlemek,

- Işten ayrılma niyetlerini ölçmek,

- Iş tatmin seviyesi, kaygı düzeyi ve işten ayrılma niyeti arasındaki ilişkileri incelemek,

- Demografik özelliklere göre anlamlı ilişkilerini belirlemek amaçlanmaktadır.

Araştırmanın hipotezleri ise şöyledir:

- $H_{1}$. Durumluk kaygı düzeyi yüksekliği iş tatminini azaltır ve işten ayrılma niyetini artırır.

- $\mathrm{H}_{2}$. Sürekli kaygı düzeyi yüksekliği iş tatminini azaltır ve işten ayrılma niyetini artırır.

- $\mathrm{H}_{3}$. Banka türlerine göre iş tatmini ve işten ayrılma niyetlerinde farklılıklar mevcuttur.

\section{Evren ve Örneklem}

Konya il merkezinde farklı kamu ve özel sektörde yer alan mevduat ve katılım bankalarında 2018-2019 yılları arasında çalışmakta olan banka çalışanları bu araştırmanın evrenini oluşturmaktadır. Bu yıllar arasında Konya ili ve ilçelerinde hizmet veren banka çalışanı sayısı toplam 3.106' dır. Bu rakamın 2.559'una Türkiye Bankalar Birliği resmi internet sitesinden, 547'sine ise katılım bankalarının bölge müdürlüklerinden ulaşılmıştır. Çalışanlara basit tesadüfi örneklem yöntemiyle 450 adet anket uygulanmış olup yapılan kontrollerde bu anketlerden 413 adedi değerlendirmeye uygun bulunmuştur. 


\section{Veri Toplama Araçları}

Araştırmadaki katılımcıların cinsiyet, medeni durum, yaş, çocuk sayısı, eğitim düzeyi, gelir düzeyi, mesleği isteyerek seçip seçmeme, çalışma süresi, bankadaki çalışma süresi, çalıştığı pozisyon, bankanın bulunduğu sektör, bankanın türü gibi çeşitli demografik verilerine ilişkin bilgi edinmek amacıyla araştırmacı tarafından bir kişisel bilgi formu oluşturulmuştur ve bu form kullanılmıştır.

Bu araştırma kapsamında iş tatmini değişkeni Minnesota İş Tatmini Ölçeğinin kısa formu kullanılarak ölçülmüştür. Ölçek Weiss, Dawis ve England (1967) tarafından geliştirilmiştir. Ölçeğin kısa formu toplamda 20 maddeden oluşmaktadır ve ölçek 5 'li Likert tipi bir ölçektir. Ölçeğe verilebilecek yanıtlar 1 (hiç tatmin edici değil) ve 5 (çok tatmin edici) arasında değişmektedir. Ölçeğin Türkçe geçerlik ve güvenirlik çalışması Baycan (1985) tarafından yapılmıştır. Ölçeğin Türkçe formunun psikometrik özelliklerinin uygun olduğu bildirilmiştir. Cronbach Alpha güvenirlik katsayısı .86 olarak rapor edilmiştir. Ölçeğin bu çalışmadaki güvenirlik katsayısı ise .91 olarak hesaplanmıştır. Bu araştırmada ölçekten alınan toplam puan kullanılmıştır.

Durumluk Sürekli Kaygı Ölçeği Spielberger, Gorsuch ve Lushene (1970) tarafından geliştirilmiştir ve Türkçe adaptasyon çalışması Öner ve Le Compte (1998) tarafından yapılmıştır. Ölçek durumluk ve sürekli kaygı olmak üzere 20'şer madde ve toplamda 40 maddeden oluşmaktadır. Ölçek 4'lü Likert tipi bir ölçektir ve verilebilecek yanıtlar 1 (hiç) ve 4 (tamamılla) şeklinde değişmektedir. Ölçeğin Türkçe geçerlik güvenirlik çalışmasındaki güvenirlik katsayıları .83 ve .87 arasında değişmektedir. Bu çalışmada güvenirlik katsayısı durumluk kaygı boyutu için .90, sürekli kaygı boyutu için ise 86 olarak hesaplanmıştır. Durumluk kaygı boyutuna ait 1, 2, 5, 8, 10, 11, 15 , 16, 19 ve 20. maddeler ile sürekli kaygı boyutuna ait olan 21, 26, 27, 30, 33, 36 ve 39. maddeler ters puanlanmaktadır.

Işten Ayrılma Niyeti Ölçeği Mobley, Horner ve Hollingsworth (1978) tarafından geliştirilmiştir ve Türkçe adaptasyonu Örücü ve Özafşarlıŏlu (2013) tarafından yapılmıştır. Ölçek toplamda 3 madde ve tek boyuttan oluşmaktadır. Ölçek 5'li Likert tipindedir ve verilebilecek yanıtlar 1 (kesinlikle katılmıyorum) ve 5 (kesinlikle katılıyorum) arasında değişmektedir.

\section{1.İşlem ve Veri Analizi}

Araştırmanın veri toplama aşamasında araştırmacı tarafından oluşturulan kişisel bilgi formu, Minnesota İş Tatmini Ölçeği, Durumluk-Sürekli Kaygı Ölçeği ve Iş̧ten Ayrılma Niyeti Ölçeği bir araya getirilerek bir ölçek hazırlanmıştır. Veri analizinden 
önce kullanılan tüm ölçeklere ilişkin güvenilirlik analizi yapılmış ve aşağıdaki sonuçlar elde edilmiştir:

Tablo 1. Araştırmada Kullanılan Ölçeklerin Güvenilirlik Katsayıları

\begin{tabular}{|c|c|c|c|c|}
\hline \multicolumn{2}{|c|}{$\begin{array}{c}\text { Minnesotalş Tatmin } \\
\text { Ölçeği }\end{array}$} & $\begin{array}{c}\text { Durumluk Kaygı } \\
\text { Ölçeği }\end{array}$ & $\begin{array}{c}\text { Sürekli Kaygı } \\
\text { Ölçeği }\end{array}$ & $\begin{array}{c}\text { Isşten Ayrılma Niyeti } \\
\text { Ölçeği }\end{array}$ \\
\hline $\begin{array}{c}\text { Cronbach Alfa } \\
\text { Katsayısı }\end{array}$ & 0.91 & 0.90 & 0.86 & 0.83 \\
\hline
\end{tabular}

Akgül ve Çelik (2003:435) ölçeğin güvenilirlik durumuna ilişkin aralıkları aşağıdaki gibi ifade etmektedir:

$0,00 \leq \alpha \leq 0,40$ ise ölçek güvenilir değildir.

$0,40 \leq \alpha \leq 0,60$ ise ölçek düşük güvenilirdir.

$0,60 \leq \alpha \leq 0,80$ ise ölçek oldukça güvenilirdir.

$0,80 \leq \alpha \leq 1,00$ ise ölçek yüksek derecede güvenilirdir.

Yukarıdaki ölçüm aralıklarına istinaden, çalışmada kullanılan tüm ölçeklerin Cronbach Alfa katsayılarının 0,8den büyük olduğu ve dolayısıyla ölçeklerin yüksek derecede güvenilir olduğu görülmüştür.

Verilerin analizi aşamasında, katılımcıların ölçeklerden aldıkları puanların demografik değişkenlere göre değişip değişmediğini tespit etmek amacıyla bağımsız gruplar t testi ve çok değişkenli varyans analizi (MANOVA) ve onu takip eden tek yönlü varyans analizi (ANOVA) yapılmıştır. Değişkenler arasındaki ilişkiler Pearson korelasyon katsayısı ile hesaplanmıştır. Daha sonra durumluk ve sürekli kaygı ile işten ayrılma niyeti arasındaki ilişkide iş tatminin aracı rolü bootstrapping yöntemiyle incelenmiştir (Preacher ve Hayes, 2004; 2008).

\section{Bulguların Değerlendirilmesi}

\subsection{Demografik Değişkenlere İlişkin Frekans Tablosu}

Bu çalışma 2018-2019 bahar döneminde farklı kamu ve özel bankalarında çalışmakta olan 152'si (\%36.8) kadın, 261'i (\%63.2) erkek olmak üzere toplamda 413 banka personeli ve yöneticisi ile yürütülmüştür. Katılımcıların demografik bilgilerine ilişkin veriler ve araştırmada kullanılan ölçeklerden alınan puanlara dair ortalama ve standart sapma değerleri Tablo 2.' de verilmiştir.

Ö. K. Ak, A. Diken, “iş Tatmini ve Kaygı Düzeyinin İşten Ayrıma Niyeti Üzerine Etkisi: Banka Çalışanları Üzerine Ampirik Bir Araştırma”, BDDK Bankacllık ve Finansal Piyasalar Dergisi, 14, (2), 2020, 175-204 
Tablo 2. Araştırmada Yer Alan Katılımcıların Demografik Verilerine iliş̧kin Bulgular

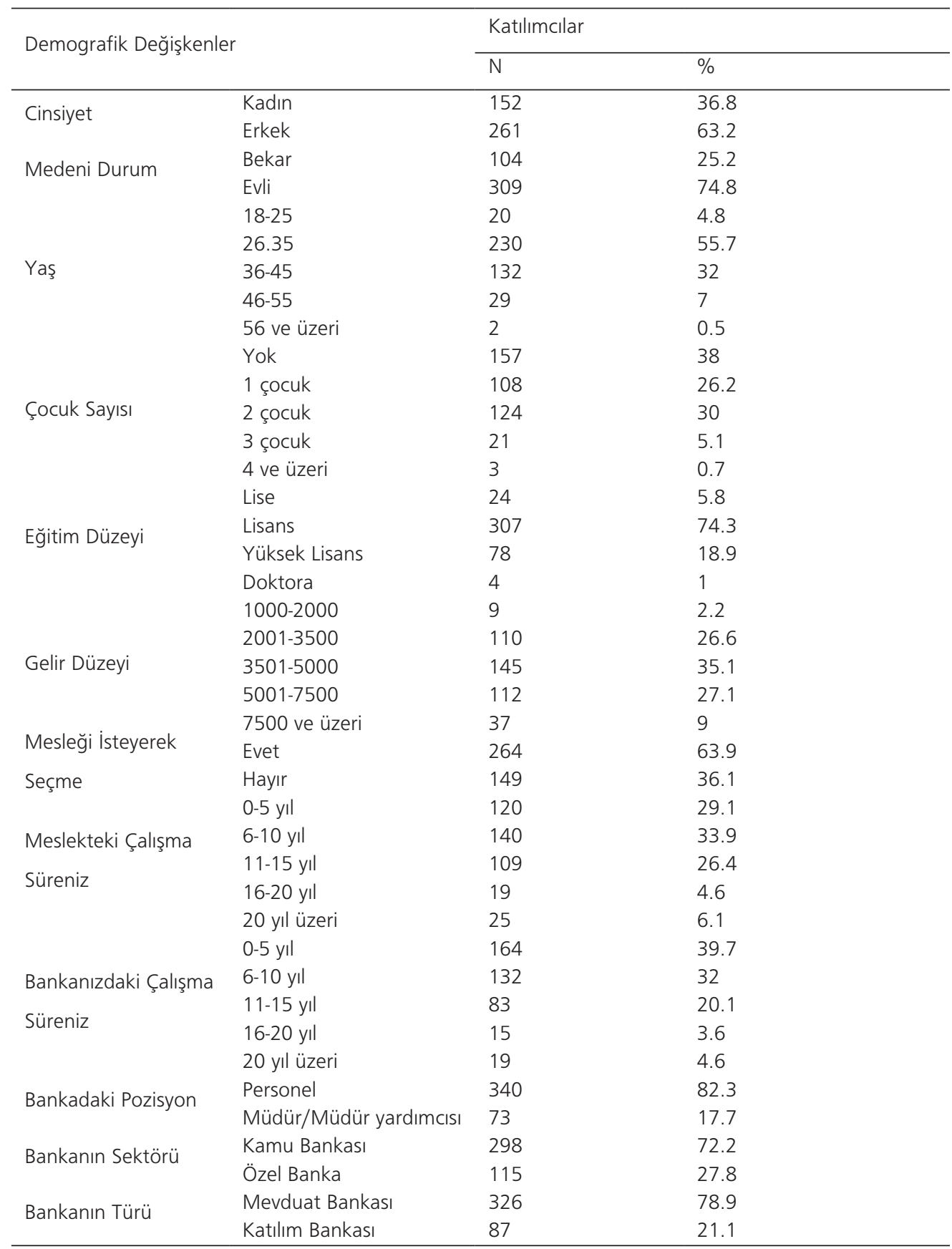




\subsection{Demografik Değişkenlere İlişkin Olarak Araştırmada Kullanılan Ölçeklerden Alınan Puanlara Uygulanan Analizlerin Sonuçları}

Analizlere başlamadan önce ilgilenilen değişkenlere hangi tür analizlerin yapılacağına karar vermek için normallik analizi yapılmış ve Kolmogorov Smirnov (K-S) testi sonuçlarına göre tüm ilgilenilen değişkenlerin normal dağılıma sahip olduğu görülmüştür.

Bu bölümde araştırmada yer alan katılımcıların demografik değişkenlerine ilişkin olarak araştırmada kullanılan ölçeklerden alınan puanlara uygulanan analizlerin sonuçlarına yer verilmiştir. Verilerin analizinde bağımsız gruplar t testi ve çok değişkenli varyans analizi (MANOVA) ile onu takip eden tek yönlü varyans analizi (ANOVA) kullanılmıştır.

Tablo 3. Katılımcıların Cinsiyetlerine ve Medeni Durumlarına Göre Durumluk-Sürekli Kaygı, İş Tatmini ve İşten Ayrılma Niyeti Puanlarının Karşılaştırılmasına İlişkin Bağımsız Gruplar t Testi Sonuçları

\begin{tabular}{llllllll}
\hline Değişkenler & Grup & $\mathrm{N}$ & Ort & Ss & $\mathrm{t}$ & $\mathrm{Sd}$ & $\mathrm{p}$ \\
\hline \multirow{2}{*}{ Iş tatmini } & Kadın & 152 & 69.38 & 10.70 & $-3.01^{* *}$ & 411 & .003 \\
& Erkek & 261 & 72.95 & 13.14 & & & \\
\hline \multirow{2}{*}{ Sürekli kaygı } & Kadın & 152 & 44.44 & 7.89 & \multirow{2}{*}{$4.87^{* *}$} & 411 & .000 \\
& Erkek & 261 & 40.16 & 8.99 & & & \\
\hline \multirow{2}{*}{ Sürekli kaygı } & Bekar & 104 & 43.39 & 9.41 & $2.22^{*}$ & 411 & .027 \\
& Evli & 309 & 41.18 & 8.58 & & & \\
\hline
\end{tabular}

Not. ${ }^{*} p<.05,{ }^{* *} p<.01$

Tablo 3.'e göre iş tatmininin cinsiyete göre istatistiksel olarak anlamlı bir farklılık göstermiştir (t $(411)=-3.01, p<.01)$. Bu farklılığın nereden kaynaklandığına bakıldığında ise erkeklerin iş tatmini puan ortalamalarının (Ort $=72.95$, Ss $=13.14$ ) kadınların iş tatmini puan ortalamalarından (Ort $=69.38$, Ss $=10.70)$ daha yüksek olduğu görülmüştür.

Sürekli kaygı boyutuna bakıldığında; sürekli kaygının cinsiyete göre istatistiksel olarak anlamlı bir farklılık gösterdiği görülmüştür (t $(411)=4.87, p<.01)$. Bu farklılığın nereden kaynaklandığına bakıldığında ise kadınların sürekli kaygı puan ortalamalarının (Ort $=44.44$, Ss $=7.89$ ) erkeklerin sürekli kaygı puan ortalamalarından yüksek olduğu (Ort $=40.16$, Ss = 8.99) görülmüştür.

Ö. K. Ak, A. Diken, "iş Tatmini ve Kaygı Düzeyinin Işten Ayrılma Niyeti Üzerine Etkisi: Banka Çalışanları Üzerine Ampirik Bir Araştırma", BDDK Bankacilık ve Finansal Piyasalar Dergisi, 14, (2), 2020, 175-204 
Cinsiyete göre durumluk kaygı (t $(411)=1.80, \mathrm{p}>.05)$ ve işten ayrılma niyeti ( $t$ $(411)=.93, p>.05)$ puan ortalamaları arasında ise anlamlı bir farklılık olmadığı tespit edilmiştir.

Tablo 4. Katılımcıların Mesleklerini İsteyerek Seçme, Bankada çalıştıkları pozisyon, Kamu ve Özel Bankada Çalışma Durumları ve Çalıştıkları Bankanın Türüne Göre Durumluk-Sürekli Kaygı, İş Tatmini ve İşten Ayrılma Niyeti Puanlarının Karşılaştırılmasına İlişkin Bağımsız Gruplar t Testi Sonuçları

\begin{tabular}{|c|c|c|c|c|c|c|c|}
\hline Değişkenler & Grup & $\mathrm{N}$ & Ort & Ss & $\mathrm{t}$ & $\mathrm{Sd}$ & $\mathrm{p}$ \\
\hline \multirow{2}{*}{ İş tatmini } & Evet & 264 & 74.39 & 12.19 & \multirow{2}{*}{$6.28^{* *}$} & \multirow{2}{*}{411} & \multirow{2}{*}{.000} \\
\hline & Hayır & 149 & 66.76 & 11.25 & & & \\
\hline \multirow{2}{*}{ Durumluk kaygı } & Evet & 264 & 39.22 & 10.64 & \multirow{2}{*}{$-4.36^{* *}$} & \multirow{2}{*}{411} & \multirow{2}{*}{.000} \\
\hline & Hayır & 149 & 43.82 & 9.68 & & & \\
\hline \multirow{2}{*}{ Sürekli kaygı } & Evet & 264 & 40.57 & 8.63 & \multirow{2}{*}{$-3.62^{* *}$} & \multirow{2}{*}{411} & \multirow{2}{*}{.000} \\
\hline & Hayır & 149 & 43.80 & 8.84 & & & \\
\hline \multirow{2}{*}{ İşten ayrılma niyeti } & Evet & 264 & 5.70 & 2.85 & \multirow{2}{*}{$-7.19^{* *}$} & \multirow{2}{*}{411} & \multirow{2}{*}{.000} \\
\hline & Hayır & 149 & 7.88 & 3.13 & & & \\
\hline \multirow{2}{*}{ İş tatmini } & PER & 340 & 70.83 & 12.63 & \multirow{2}{*}{$-2.87^{* *}$} & \multirow{2}{*}{411} & \multirow{2}{*}{.004} \\
\hline & $\mathrm{M} / \mathrm{MY}$ & 73 & 75.38 & 10.56 & & & \\
\hline \multirow{2}{*}{ İş tatmini } & Kamu & 298 & 70.26 & 11.94 & \multirow{2}{*}{$-3.69^{* *}$} & \multirow{2}{*}{411} & \multirow{2}{*}{.000} \\
\hline & Özel & 115 & 75.21 & 12.92 & & & \\
\hline \multirow{2}{*}{ Durumluk kaygı } & Kamu & 298 & 41.85 & 10.53 & \multirow{2}{*}{$3.03^{* \star}$} & \multirow{2}{*}{411} & \multirow{2}{*}{.003} \\
\hline & Özel & 115 & 38.38 & 10.14 & & & \\
\hline \multirow{2}{*}{ Sürekli kaygı } & Kamu & 298 & 42.42 & 8.98 & \multirow{2}{*}{$2.52^{*}$} & \multirow{2}{*}{411} & \multirow{2}{*}{.012} \\
\hline & Özel & 115 & 39.98 & 8.24 & & & \\
\hline İsten ayrılma niveti & Kamu & 298 & 6.84 & 3.14 & $3.72^{* *}$ & 411 & 000 \\
\hline işten dyrimand myeu & Özel & 115 & 5.58 & 2.90 & 3.12 & 411 & .000 \\
\hline & MEV & 326 & 70.11 & 11.92 & $19 Q^{* *}$ & 111 & קم \\
\hline Iş̧ tatmını & KAT & 87 & 77.36 & 12.57 & -4.98 & 411 & .000 \\
\hline & MEV & 326 & 41.77 & 10.61 & $334^{* *}$ & 411 & 001 \\
\hline Durumiuk kaygi & KAT & 87 & 37.57 & 9.52 & 3.34 & 411 & .001 \\
\hline & MEV & 326 & 42.57 & 8.84 & & & \\
\hline sureklı kaygı & KAT & 87 & 38.63 & 8.15 & 3.15 & 411 & .000 \\
\hline İsten a & MEV & 326 & 6.83 & 3.14 & $436^{* *}$ & 411 & مी \\
\hline Işten dyrimand myeu & KAT & 87 & 5.22 & 2.75 & 4.50 & 411 & .000 \\
\hline
\end{tabular}

Not. ${ }^{*} p<.05,{ }^{* *} p<.01$

Tablo 4.'te sürekli kaygının medeni duruma göre istatistiksel olarak anlamlı bir farklılık gösterdiği görülmektedir (t $(411)=2.22, p<.05)$. Bu farklılığın nereden kaynaklandığına bakıldığında ise bekârların sürekli kaygı puan ortalamalarının (Ort = 43.39, Ss $=9.41$ ) evlilerin sürekli kaygı puan ortalamalarından (Ort $=41.18$, Ss $=$ 8.58) yüksek olduğu görülmüştür.

Medeni duruma göre iş tatmini $(\mathrm{t}(411)=.44, \mathrm{p}>$.05) durumluk kaygı $(\mathrm{t}(411)=$ 
$1.65, \mathrm{p}>.05)$ ve işten ayrılma niyeti $(\mathrm{t}(411)=.66, \mathrm{p}>.05)$ puan ortalamaları arasında ise anlamlı bir farklılık olmadığı tespit edilmiştir.

İ̧ tatmininin katılımcıların mesleklerini isteyerek seçme durumlarına göre istatistiksel olarak anlamlı bir farklılık gösterdiği bulunmuştur (t $(411)=6.28, p<.01)$. Bu farklılığın mesleğini isteyerek seçenlerin iş tatmini puan ortalamalarının (Ort = 74.39, Ss = 12.19) mesleğini isteyerek seçmeyenlerin iş tatmini puan ortalamalarından (Ort $=66.76$, Ss $=11.25$ ) yüksek olmasından kaynaklandığı görülmüştür.

Durumluk kaygı boyutuna bakıldığında; durumluk kaygının katılımcıların mesleklerini isteyerek seçme durumlarına göre istatistiksel olarak anlamlı bir farklılık gösterdiği görülmüştür (t (411) = -4.36, p<.01). Bu farklılığın nereden kaynaklandığına bakıldığında ise mesleğini isteyerek seçenlerin durumluk kaygı puan ortalamalarının (Ort $=39.22$, Ss $=10.64$ ) mesleğini isteyerek seçmeyenlerin durumluk kaygı puan ortalamalarından düşük olduğu (Ort $=43.82$, Ss $=9.68$ ) ve aradaki farkın istatistiksel olarak anlamlı olduğu görülmüştür.

Sürekli kaygı boyutunda ise, sürekli kaygının katılımcıların mesleklerini isteyerek seçme durumlarına göre istatistiksel olarak anlamlı bir farklılık gösterdiği bulunmuş$\operatorname{tur}(\mathrm{t}(411)=-3.62, \mathrm{p}<.01)$. Bu farklılığın nereden kaynaklandığına bakıldığında ise mesleğini isteyerek seçenlerin sürekli kaygı puan ortalamalarının (Ort $=40.57$, Ss = 8.63) mesleğini isteyerek seçmeyenlerin sürekli kaygı puan ortalamalarından düşük olduğu (Ort $=43.80$, Ss $=8.84$ ) görülmüştür.

Işsten ayrılma niyetine bakıldığında ise işten ayrılma niyetinin katılımcıların mesleklerini isteyerek seçme durumlarına göre istatistiksel olarak anlamlı bir farklılık gösterdiği belirlenmiştir (t (411) =-7.19, p<.01). Bu farklılığın nereden kaynaklandığına bakıldığında ise mesleğini isteyerek seçenlerin işten ayrılma niyeti puan ortalamalarının (Ort $=5.70$, Ss $=2.85$ ) mesleğini isteyerek seçmeyenlerin işten ayrılma niyeti puan ortalamalarından düşük olduğu (Ort $=7.88$, Ss = 3.13) görülmüştür.

İş tatmininin katılımcıların bankada çalıştıkları pozisyona göre istatistiksel olarak anlamlı bir farklıık gösterdiği görülmüştür (t $(411)=-2.87, p<.01)$. Bu farklılığın nereden kaynaklandığına bakıldığında ise bankada müdür/müdür yardımcısı pozisyonunda çalışanların iş tatmini puan ortalamalarının (Ort $=75.38$, Ss $=10.56$ ) personel pozisyonunda çalışanların iş tatmini puan ortalamalarından (Ort $=70.83$, Ss $=12.63$ ) yüksek olduğu görülmüştür.

Bankada çalışılan pozisyona göre durumluk kaygı (t $(411)=.24, p>$.05) sürekli kaygı $(t(411)=1.65, p>.05)$ ve işten ayrılma niyeti $(t(411)=1.60, p>.05)$ puan or-

Ö. K. Ak, A. Diken, “iş Tatmini ve Kaygı Düzeyinin İşten Ayrıma Niyeti Üzerine Etkisi: Banka Çalışanları Üzerine Ampirik Bir Araştırma”, BDDK Bankacllık ve Finansal Piyasalar Dergisi, 14, (2), 2020, 175-204 
talamaları arasında ise anlamlı bir farklılık olmadığı tespit edilmiştir.

İş tatmininin katılımcıların kamu ve özel bankada çalışma durumlarına göre istatistiksel olarak anlamlı bir farklılık gösterdiği görülmüştür (t $(411)=-3.69, p<.01)$. Bu farklılığın nereden kaynaklandığına bakıldığında ise kamu bankasında çalışanların iş tatmini puan ortalamalarının (Ort $=70.26$, Ss $=11.94$ ) özel bankada çalışanların iş tatmini puan ortalamalarından (Ort $=75.21$, Ss $=12.92$ ) düşük olduğu görülmüştür.

Durumluk kaygı boyutuna bakıldığında; durumluk kaygının katılımcıların kamu ve özel bankada çalışma durumlarına göre istatistiksel olarak anlamlı bir farklılık gösterdiği bulunmuştur(t $(411)=3.03, p<.01)$. Bu farklılığın nereden kaynaklandığına bakıldığında ise durumluk kaygı puan ortalamalarının (Ort $=41.85$, Ss $=10.53$ ) özel bankada çalışanların durumluk kaygı puan ortalamalarından yüksek olduğu (Ort = 38.38, Ss = 10.14) ve aradaki farkın istatistiksel olarak anlamlı olduğu görülmüştür.

Sürekli kaygı boyutunda ise sürekli kaygının katılımcıların kamu ve özel bankada çalışma durumlarına göre istatistiksel olarak anlamlı bir farklılık gösterdiği bulunmuştur $(t(411)=2.52, p<.05)$. Bu farklılığın nereden kaynaklandığına bakıldığında ise kamu bankasında çalışanların sürekli kaygı puan ortalamalarının (Ort $=42.42$, Ss = 8.98) özel bankada çalışanların sürekli kaygı puan ortalamalarından yüksek olduğu (Ort $=39.98$, Ss $=8.24$ ) görülmüştür.

İşten ayrılma niyetine bakıldığında ise işten ayrılma niyetinin katılımcıların kamu ve özel bankada çalışma durumlarına göre istatistiksel olarak anlamlı bir farklıık gösterdiği görülmüştür (t $(411)=3.72, p<.01)$. Bu farklılı̆ın nereden kaynaklandığına bakıldığında ise kamu bankasında çalışanların işten ayrılma niyeti puan ortalamalarının (Ort $=6.84$, Ss = 3.14) Özel bankada çalışanların işten ayrılma niyeti puan ortalamalarından yüksek olduğu (Ort $=5.58$, Ss $=2.90)$ görülmüştür.

İş tatmininin katıımcıların çalıştıkları bankanın türüne göre istatistiksel olarak anlamlı bir farklılık gösterdiği(t (411) = -4.98, p<.01), bu farklılığın da mevduat bankasında çalışanların iş tatmini puan ortalamalarının (Ort $=70.11$, Ss $=11.92$ ) katıım bankasında çalışanların iş tatmini puan ortalamalarından (Ort $=77.36$, Ss $=12.57$ ) düşük olmasından kaynaklandığı görülmüştür.

Durumluk kaygı boyutuna bakıldığında; durumluk kaygının katılımcıların çalıştıkları bankanın türüne göre istatistiksel olarak anlamlı bir farklılık gösterdiği belirlenmiştir $(t(411)=3.34, p<.01)$. Bu farklıığın nereden kaynaklandığına bakıldığında ise mevduat bankasında çalışanların durumluk kaygı puan ortalamalarının (Ort = 41.77, Ss $=10.61)$ katılım bankasında çalışanların durumluk kaygı puan ortalamalarından 
yüksek olduğu (Ort = 37.57, Ss = 9.52) görülmüştür.

Sürekli kaygı boyutunda ise sürekli kaygının katılımcıların çalıştıkları bankanın türüne göre istatistiksel olarak anlamlı bir farklılık gösterdiği (t (411) = 3.75, p<.01) ve bu farklılığın mevduat bankasında çalışanların sürekli kaygı puan ortalamalarının (Ort $=42.57$, Ss $=8.84$ ) katılım bankasında çalışanların sürekli kaygı puan ortalamalarından yüksek olmasından (Ort = 38.63, Ss = 8.15) kaynaklandığı görülmüştür.

İşten ayrılma niyetine bakıldığında ise işten ayrılma niyetinin katılımcıların çalıştıkları bankanın türüne göre istatistiksel olarak anlamlı bir farklılık gösterdiği (t (411) $=4.36, p<.01)$ ve mevduat bankasında çalışanların işten ayrılma niyeti puan ortalamalarının (Ort $=6.83$, Ss $=3.14$ ) katılım bankasında çalışanların işten ayrılma niyeti puan ortalamalarından yüksek olduğu (Ort $=5.22$, Ss $=2.75)$ görülmüştür.

Araştırmaya dahil edilen katılımcıların sahip oldukları çocuk sayısı, yaşları, eğitim düzeyleri, gelir düzeyleri, mesleklerindeki çalışma yılı ve çalıştıkları bankadaki çalışma süreleri değişkenlerinin iş tatmini, durumluk kaygı, sürekli kaygı ve işten ayrılma niyeti puanları açısından farklılaşıp farklılaşmadığının belirlenmesi amacıyla çok değişkenli varyans analizi (MANOVA) ve onu takip eden tek değişkenli varyans analizi (ANOVA) sonuçlarına yer verilmiştir. Yapılan analizler sonucunda çocuk sayısı, yaş, eğitim düzeyi, meslekteki çalışma yılı değişkenlerine göre iş tatmini, durumluk kaygı, sürekli kaygı ve işten ayrılma niyeti puanları açısından herhangi bir farklılık olmadığı tespit edilmiştir. Bu nedenle burada katılımcıların gelir düzeyi ve bankadaki çalışma süreleri açısından bulunan farklılıklar rapor edilmiştir.

Tablo 5. Katılımcıların Gelir Düzeyine Göre İş Tatmini, Durumluk-Sürekli Kaygı ve İşten Ayrılma Niyeti Değişkenlerinden Alınan Puanlara Uygulanan MANOVA Sonuçları

\begin{tabular}{lllllll}
\hline Etki & Wilks' $\lambda$ & Sd & Hata sd & $F$ & $P$ & $\eta^{2}$ \\
\hline Gelir Düzeyi & .883 & 16 & 1237.93 & 3.21 & .000 & .03 \\
\hline
\end{tabular}

Gelir düzeyinin iş tatmini, durumluk ve sürekli kaygı ile işten ayrılma niyeti değişkenlerinden alınan puanlar üzerindeki etkilerine ilişkin MANOVA sonuçları Tablo 5.'de gösterilmiştir. Tablo 5.'den de görülebileceği gibi gelir düzeyinin $\left(F_{4.16}=3.21\right.$; $\left.\mathrm{p}<.01, \eta^{2}=.03\right)$ temel etkisi anlamlıdır. Çok değişkenleri varyans analizini izleyen (MANOVA) tek değişkenli varyans analizi (ANOVA) sonuçları Tablo 6.'da gösterilmiştir.

Ö. K. Ak, A. Diken, “iş Tatmini ve Kaygı Düzeyinin İşten Ayrıma Niyeti Üzerine Etkisi: Banka Çalışanları Üzerine Ampirik Bir Araştırma”, BDDK Bankacılık ve Finansal Piyasalar Dergisi, 14, (2), 2020, 175-204 
Tablo 6. Gelir Düzeyi Değişkenine Göre İş Tatmini, Durumluk-Sürekli Kaygı ve İşten Ayrılma Niyeti Değişkenlerinden Alınan Puanlara iliş̧kin ANOVA Sonuçları

\begin{tabular}{llllll}
\hline \multicolumn{2}{l}{ Değişim kaynağı: Gelir Düzeyi (1:413) } & \multicolumn{1}{l}{} & \\
\hline Değişken & Kar. Toplamı & Ort. Kare & $F$ & $p$ & $\eta^{2}$ \\
\hline İş tatmini & 1793.59 & 448.40 & 2.97 & .019 & .03 \\
Durumluk kaygı & 497.72 & 124.43 & 1.12 & .344 & .01 \\
Sürekli kaygı & 1685.35 & 421.34 & 5.64 & .000 & .05 \\
Işsten ayrılma niyeti & 21.96 & 5.49 & .56 & 0.69 & .00 \\
\hline
\end{tabular}

Tablo 6.' da görüldüğü üzere iş tatmininin gelire göre istatistiksel olarak anlamlı bir farklılık gösterdiği $\left(F_{1-413}=2.97, p<.05, \eta^{2}=.03\right)$ görülmüş, bu farklıığın nereden kaynaklandığını saptamak amacıyla Tukey testi yapılmış ve elde edilen sonuçlar her ne kadar gelir düzeyine göre iş tatmini puanlarında bir farklılık olsa da bu farkın anlamlı olmadığını göstermiştir.

Sürekli kaygı boyutuna bakıldığında sürekli kaygının gelire göre istatistiksel olarak anlamlı bir farklılık gösterdiği görülmüştür $\left(F_{1-413}=5.64, p<.01, \eta^{2}=.05\right)$. Bu farkIılığın nereden kaynaklandığını saptamak amacıyla Tukey testi yapılmış ve 5001€7500‡ (Ort $=38.61$, Ss $=8.59$ ) arası gelire sahip olanların 2001€ - 3500‡ (Ort = 42.89 , Ss $=8.92$ ) ve $3501-5000$ (Ort $=43.19$, Ss $=8.22$ ) arası gelire sahip olanlara göre daha düşük düzeyde sürekli kaygıya sahip oldukları tespit edilmiştir.

Tablo 7. Katılımcıların Bankada Çalışma Sürelerine Göre İş Tatmini, Durumluk-Sürekli Kaygı ve İşten Ayrılma Niyeti Değişkenlerinden Alınan Puanlara Uygulanan MANOVA Sonuçları

\begin{tabular}{lllllll}
\hline Etki & Wilks' $\lambda$ & Sd & Hata sd & $F$ & P & $\eta^{2}$ \\
\hline $\begin{array}{l}\text { Bankada Çalışma } \\
\text { Süresi }\end{array}$ & .934 & 16 & 1237.93 & 1.75 & .032 & .02 \\
\hline
\end{tabular}

Katılımcıların bankada çalışma sürelerine göre iş tatmini, durumluk ve sürekli kaygı ile işten ayrıma niyeti değişkenlerinden alınan puanlar üzerindeki etkilerine ilişkin MANOVA sonuçları Tablo 7.'de gösterilmiştir. Tablo 7.'den de görülebileceği gibi gelir düzeyinin $\left(F_{4.16}=1.75 ; p<.01, \eta^{2}=.02\right)$ temel etkisi anlamlıdır. Çok değişkenleri varyans analizini izleyen (MANOVA) tek değişkenli varyans analizi (ANOVA) sonuçları Tablo 8.' de gösterilmiştir. 
Tablo 8. Bankada Çalışma Süresi Değişkenine Göre İş Tatmini, Durumluk-Sürekli Kaygı ve İşten Ayrılma Niyeti Değişkenlerinden Alınan Puanlara İlişkin ANOVA Sonuçları

\begin{tabular}{llllll}
\hline \multicolumn{6}{l}{ Değişim kaynağı: Bankada Çalışma Süresi (1:413) } \\
\hline Değişken & Kar. Toplamı & Ort. Kare & $F$ & $p$ & $\eta^{2}$ \\
\hline Iş̧ tatmini & 1037.66 & 259.41 & 1.70 & .150 & .02 \\
Durumluk kaygı & 893.51 & 223.38 & 2.04 & .088 & .02 \\
Sürekli kaygı & 318.05 & 79.51 & 1.02 & .398 & .01 \\
Işsten ayrılma niyeti & 127.23 & 31.81 & 3.33 & .011 & .03 \\
\hline
\end{tabular}

Tablo 8.'de görüldüğü üzere işten ayrılma niyetinin bankada çalışma süresi değişkenine göre istatistiksel olarak anlamlı bir farklılık göstermiştir $\left(F_{1-413}=3.33, p<\right.$ $\left..05, \eta^{2}=.03\right)$. Bu farklılığın nereden kaynaklandığını saptamak amacıyla Tukey testi yapılmıştır. Elde edilen bankada çalışma süresine göre işten ayrılma niyeti açısından bulunan farklılığın anlamlı olduğu ve 6-10 yıldır çalışanların (Ort = 7.13, Ss = 3.37) $0-5$ yıldır (Ort $=6.01$, Ss = 3.03) çalışanlara göre işten ayrılma niyetlerinin daha yüksek olduğu tespit edilmiştir.

\subsection{Durumluk ve Sürekli Kaygı ile İşten Ayrılma Niyeti Arasındaki İlişkide İş Tatminin Aracı Rolüne İlişkin Olarak Elde Edilen Bulgular}

Araştırmanın bu bölümünde toplamda iki ayrı aracılık analizi yapılmıştır. İlk olarak durumluk kaygı ve işten ayrılma niyeti arasındaki ilişkide iş tatmininin aracı rolü, ikinci olarak ise sürekli kaygı ve işten ayrılma niyeti arasındaki ilişkide iş tatmininin aracı rolü incelenmiştir. Aracılık analizleri Preacher ve Hayes $(2004 ; 2008)$ tarafından önerilen bootstrapping yöntemi ile ve process macro yardımılla yürütülmüştür. Aracılık analizleri Hayes tarafından geliştirilen Process Macro yardımıyla yapılmıştır. Process macro ile bootstrapping yöntemi kullanılmıştır, çünkü bu şekilde tek bir p değeri yerine bir güven aralığı elde edilmektedir. Bu da sonuçları daha güçlü hale getirmektedir. Ayrıca aracılık analizi sonuçlarında kısmi aracı değişken rolünün anlamlılığını test etmek amacıyla da Sobel testi kullanılmıştır ve rapor edilmiştir.

Aracılık analizlerinden önce durumluk-sürekli kaygı, iş tatmini ve işten ayrılma niyeti değişkenleri arasındaki ilişkiye dair korelasyon analizleri, ortalama ve standart sapma değerleri ile çarpıklık ve basıklık katsayıları Tablo 9.'da gösterilmiştir.

Ö. K. Ak, A. Diken, “iş̧ Tatmini ve Kaygı Düzeyinin İşten Ayrılma Niyeti Üzerine Etkisi: Banka Çalışanları Üzerine Ampirik Bir Araştıma”, BDDK Bankacilık ve Finansal Piyasalar Dergisi, 14, (2), 2020, 175-204 
Tablo 9. Araştırmada Kullanılan Değişkenler Arasındaki İlişkiler, Ortalama, Standart Sapma Değerleri ve Çarpıklık ve Basıklık Katsayıları

\begin{tabular}{lllllll}
\hline & 1 & 2 & 3 & 4 & Çarpıklık & Basıklık \\
\hline DK & - & & & .544 & -.069 \\
SK & $.55^{* *}$ & - & & .407 & .434 \\
\hline IT & $-.56^{* *}$ & $-.43^{* *}$ & - & & -.275 & .281 \\
IAN & $.55^{* *}$ & $.42^{* *}$ & $-.49^{* *}$ & - & .848 & .201 \\
\hline X & 40.88 & 41.74 & 71.64 & 6.49 & & \\
S & 10.52 & 8.84 & 12.40 & 3.13 & & \\
\hline
\end{tabular}

Not.DK: Durumluk kaygı, SK: Sürekli kaygı, iT: İş tatmini, IAN: İşten ayrılma niyeti, ${ }^{*} p<.05,{ }^{* *} p<.01$

Salkind (2015: 88)' e göre korelasyon katsayısının yorumlanmasına dair Tablo 10. şu şekildedir:

\section{Tablo 10. Korelasyon Katsayılarına İlişkin Yorumlama}

\begin{tabular}{|l|l|}
\hline Korelasyonun Büyüklüğü & Katsayının Genel Yorumu \\
\hline .8 ile 1.0 arası & Çok güçlü ilişki \\
\hline .6 ile .8 arası & Güçlü ilişki \\
\hline .4 ile .6 arası & Orta dereceli ilişki \\
\hline .2 ile .4 arası & Zayıf ilişki \\
\hline .0 ile .2 arası & Zayıf ilişki veya ilişki yok \\
\hline
\end{tabular}

Tablo 10.' dan da görülebileceği gibi durumluk kaygı düzeyi ile iş tatmini arasında negatif yönlü bir ilişki olduğu( $r=-.56, p<.001)$ ve iki değişken arasındaki negatif yönlü ilişki de aynı zamanda orta düzeyde olduğu görülmüştür.

Durumluk kaygı düzeyi ile işten ayrılma niyeti arasında pozitif yönlü,orta düzeyde bir ilişki olduğu $(r=.55, p<.01)$ görülmüştür.

Sürekli kaygı düzeyi ile iş tatmini arasında negatif yönlü,orta düzeyde bir ilişki olduğu( $r=-.43, p<.01)$ bulunmuştur.

Sürekli kaygı düzeyi ile işten ayrılma niyeti arasında pozitif yönlü,orta düzeyde bir ilişki $(r=.42, p<.01)$ görülmüştür.

İş tatmini ile işten ayrıma niyeti arasında negatif yönlü, orta düzeyde bir ilişki olduğuna $(r=-.49, p<.01)$ bulunmuştur.

Sonuç olarak, çalışmanın $\mathrm{H}_{1}, \mathrm{H}_{2}$ ve $\mathrm{H}_{3}$ hipotezlerinin doğrulandığı görülmüştür. 


\subsection{Durumluk Kaygı ile İşten Ayrılma Niyeti Arasındaki İlişkide İş Tatmininin Aracı Rolüne İlişkin Olarak Elde Edilen Bulgular}

Bu bölümde durumluk kaygı ile işten ayrılma niyeti arasındaki ilişkide iş tatmininin aracı rolü incelenmiştir. Yapılan bootstrapping analizi sonucu elde edilen doğrudan, dolaylı ve toplam etkiler Tablo 11.'de gösterilmiştir.

Tablo 11. Durumluk Kaygı ve İşten Ayrılma Niyeti Arasındaki İlişkide İş Tatmininin Aracı Rolüne İlişkin Bootstrapping Sonuçları

\begin{tabular}{lllll}
\hline \multirow{2}{*}{ Yol } & \multicolumn{2}{l}{ Bootstrapping } & \multicolumn{2}{l}{ \%95 Güven Aralığı (GA) } \\
\cline { 2 - 5 } & B & SH & Alt Limit & Üst Limit \\
\hline Total Etki & .16 & .01 & .14 & .19 \\
DK $\rightarrow$ iAN & & & & .15 \\
Doğrudan Etki & .12 & .01 & .09 & -.57 \\
DK $\rightarrow$ iAN & -.66 & .05 & -.75 & -.04 \\
DK $\rightarrow$ iT & -.07 & .01 & -.09 & .06 \\
IT $\rightarrow$ iAN & & & & .03 \\
Dolaylı Etki & .04 & .01 & & \\
DK $\rightarrow$ iT $\rightarrow$ iAN & & &
\end{tabular}

Not.DK: Durumluk kaygı, iT: İ̧̧ tatmini, IAN: İşten ayrılma niyeti

Durumluk kaygı ve işten ayrılma niyeti arasındaki ilişkide iş tatminin aracı rolüne ilişkin olarak yürütülen bootstrapping sonuçları Tablo 11.'de gösterilmiştir. Tablo 11.'den de görülebileceği gibi durumluk kaygı hem iş tatminini $(B=-.66, \mathrm{SH}=.05$, 95\% GA $[-.75,-.57])$ hem de işten ayrılma niyetini ( $B=.16, \mathrm{SH}=.01,95 \% \mathrm{GA}[.14$, .19]) yordamaktadır. İş tatmini de işten ayrılma niyetini yordamaktadır ( $B=-.07, \mathrm{SH}$ $=.01,95 \%$ GA $[-.09,-.04]$ ). Durumluk kaygı ve işten ayrılma niyeti arasındaki dolaylı etki incelendiğinde de iş tatmininin durumluk kaygı ve işten ayrılma niyeti arasındaki ilişki kısmi aracı rolü olduğu görülmektedir ( $\mathrm{B}=.04, \mathrm{SH}=.01,95 \% \mathrm{GA}[.03, .06])$. Sobel testi skoru da söz konusu bu kısmi aracı etkinin anlamlı olduğunu göstermektedir $(z=5.02, p<.001)$. Durumluk kaygı ve işten ayrılma niyeti arasındaki ilişkide iş tatmininin aracı etkisine ilişkin model Şekil 1.'de gösterilmiştir. 
Şekil 1. Durumluk Kaygı ile İşten Ayrılma Niyeti Arasındaki i̇lişkide İş Tatminin Aracı Etkisine İlişkin Yol Katsayıları

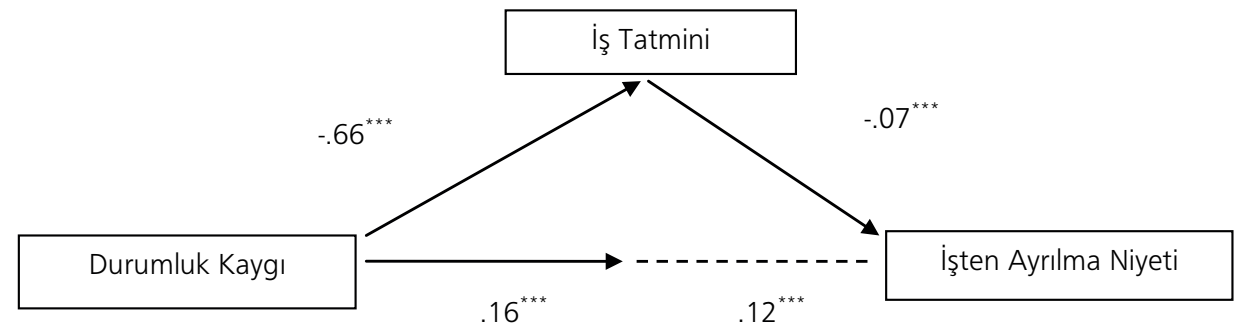

${ }^{*} p<.05,{ }^{* *} p<.01,{ }^{* * *} p<.001$

\subsection{Sürekli Kaygı ile İşten Ayrılma Niyeti Arasındaki İlişkide İş Tat- mininin Aracı Rolüne İlişkin Olarak Elde Edilen Bulgular}

Bu bölümde sürekli kaygı ile işten ayrılma niyeti arasındaki ilişkide iş tatminin aracı rolü incelenmiştir. Yapılan bootstrapping analizi sonucu elde edilen doğrudan, dolayIı ve toplam etkiler Tablo12.' de gösterilmiştir.

Tablo 12. Sürekli Kaygı ve İşten Ayrılma Niyeti Arasındaki İlişkide İş Tatmininin Aracı Rolüne İlişkin Bootstrapping Sonuçları

\begin{tabular}{|c|c|c|c|c|}
\hline \multirow{2}{*}{ Yol } & \multicolumn{2}{|c|}{ Bootstrapping } & \multicolumn{2}{|c|}{ \%95 Güven Aralığı (GA) } \\
\hline & B & $\mathrm{SH}$ & Alt Limit & Üst Limit \\
\hline \multicolumn{5}{|l|}{ Total Etki } \\
\hline SK $\rightarrow$ IAN & .15 & .02 & .12 & .18 \\
\hline \multicolumn{5}{|c|}{ Doğrudan Etki } \\
\hline SK $\rightarrow$ IAN & .09 & .02 & .06 & .13 \\
\hline $\mathrm{SK} \rightarrow \mathrm{iT}$ & -.60 & .06 & -.73 & -.48 \\
\hline iT $\rightarrow$ IAN & -.09 & .01 & -.11 & -.07 \\
\hline \multicolumn{5}{|l|}{ Dolaylı Etki } \\
\hline SK $\rightarrow$ ITàiAN & .06 & .01 & .04 & .08 \\
\hline
\end{tabular}

Not.SK: Sürekli kaygı, iT: Iş̧ tatmini, IAN: Iş̧ten ayrılma niyeti

Sürekli kaygı ve işten ayrılma niyeti arasındaki ilişkide iş tatmininin aracı rolüne ilişkin olarak yürütülen bootstrapping sonuçları Tablo 12.'de gösterilmiştir. Tablo 12.'den de görülebileceği gibi sürekli kaygı hem iş tatminini ( $B=-.60, \mathrm{SH}=.06,95 \%$ $\mathrm{GA}[-.73,-.48])$ hem de işten ayrılma niyetini ( $\mathrm{B}=.15$, SH $=.02,95 \% \mathrm{GA}[.12, .18])$ yordamaktadır. İş tatmini de işten ayrılma niyetini yordamaktadır $(B=-.09, \mathrm{SH}=.01$, 
95\% GA [-.11, -.07]). Sürekli kaygı ve işten ayrılma niyeti arasındaki dolaylı etki incelendiğinde de iş tatmininin sürekli kaygı ve işten ayrılma niyeti arasındaki ilişki kısmi aracı rolü olduğu görülmektedir ( $B=.06, \mathrm{SH}=.01,95 \% \mathrm{GA}[.04, .08])$. Sobel testi skoru da söz konusu bu kısmi aracı etkinin anlamlı olduğunu göstermektedir (z = $6.18, p<.001)$. Sürekli kaygı ve işten ayrılma niyeti arasındaki ilişkide iş tatminin aracı etkisine ilişkin model Şekil 2.'de gösterilmiştir.

Şekil 2. Sürekli Kaygı ile İşten Ayrılma Niyeti Arasındaki İlişkide İş Tatminin Aracı Etkisine İlişkin Yol Katsayıları

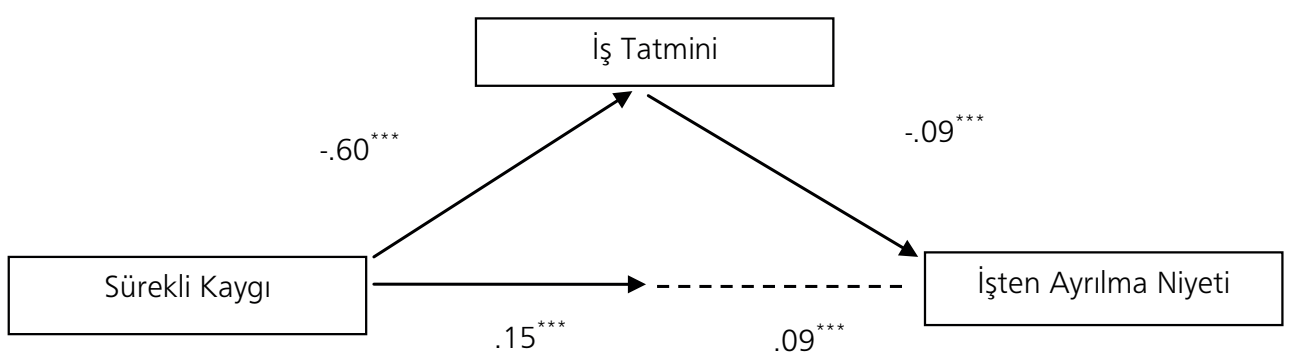

${ }^{*} p<.05,{ }^{* *} p<.01,{ }^{* * *} p<.001$

\section{Sonuç ve Öneriler}

Bu çalışmanın nihai amacı banka çalışanlarının kaygı düzeylerinin ve iş tatminlerinin, işten ayrılma niyeti üzerindeki etkisini incelemektir. Çalışmada aynı zamanda çalışanların demografik özellikleriyle işten ayrılma niyetleri arasındaki ilişkinin tanımlanması amaçlanmıştır.

Çalışmamızın bulguları incelendiğinde erkek çalışanların kadın çalışanlara göre işlerinden daha memnun oldukları görülmüştür. Çalışmanın bu sonuçları benzer şekilde erkeklerde iş tatmini yüksek bulanlarla uyumludur (Hulin ve Smith, 1964; Okpara, 2006; Çarıkçı, 2004, Al- Mashaan, 2003). Ancak tersini de rapor eden araştırmalar mevcuttur (Imran vd., 2010; Eğinli, 2009; Groot vd., 1999; Kaya ve Oğuzöncül, 2016; Lambert vd., 2001). Bu sonucun nedenie yönelik analiz yapıldığında; seçilen örneklemin yaşadığı şehirde erkek çalışanların kadın çalışanlara nazaran tercih edilirliğinin fazla olması, kadın çalışanların bu nedenle pazarlama faaliyetlerinin gerekliliğini erkek çalışanlara oranla daha zor şartlarda gerçekleştirebilmesi, sosyal etkenlerin kadın çalışanlar açısından bir dezavantaj olmasının etken olabileceği düşünülmüştür. Ayrıca kadın çalışanların yerine getirmek zorunda oldukları aile, çocuklar ve sosyalleşme gibi sorumlulukları nedeniyle daha fazla mesai dışı zamana ihtiyaçları olması da 
bu sonucu destekler niteliktedir. Yönetici seçiminde kadın çalışanların erkek çalışanlara oranla daha az tercih edilmesi de kadın çalışanların işlerinden daha az memnun olmasına yol açabilmektedir.

Yalnızca meslek seçiminde değil, insanın yaşamında yapacağı tüm işleri isteyerek yapması o iş ile ilgili beklentilerin gerçekleşme olasılığını arttırarak kişinin tatmin olmasını ve neticede işten ayrılma niyetinin az olmasına neden olur. Birçok araştırmada mesleğini isteyerek seçenlerin iş tatmininin, mesleğini isteyerek seçmeyenlerin iş tatmininden yüksek ve işten ayrılma niyetlerinin düşük çıktığı bildirilmiş ve bu sonuç araştırma bulgularımızca da desteklenmiştir (Gökdeniz ve Merdan, 2016; Kök ve Çakıcı, 2016; Kaya ve Oğuzöncül, 2016). Günümüzde insanların kendi beceri ve yeteneklerine uygun meslek seçmesi yerine özellikle yüksek ücret faktörünü dikkate alarak seçim yapması, ilerleyen yıllarda beklentilerin değişmesi neticesinde ihtiyaç duyacağı özerklik, saygınlık ve statü gibi faktörleri dikkate almaması, sonrasında kişinin işinden duyacağı tatminin azalmasına yol açabileceğinden, çalışanın işiyle ilgili beklentilerini daha en başında belirlemesi ve bu doğrultuda istediği meslekle ilgili ayrıntılı araştırma yapması ileride yaşanacak olası sorunların önüne geçmesi açısından yararlı olacaktır. Birey isteyerek seçmiş olduğu mesleği sayesinde yaşamış olduğu tatmin neticesinde kendini gerçekleştirerek hem fiziksel hem de psikolojik açıdan daha sağlıklı ve güçlü bir yapıya sahip olacaktır.

Bulgularda ortaya çıkan özel banka çalışanlarında, kamu bankalarında çalışanlara göre daha yüksek düzeyde bir iş tatmininin nedenleri arasında, kamu bankalarında çalışanların karar verme yetkilerindeki kısıtlık, düşük özerklik, düşük performansın katî bir yaptırımının olmamasından kaynaklı yüksek performansa sahip çalışanın demoralize olması ve hiyerarşi nedeniyle yöneticilerle iletişimin daha dar kapsamda olması sayılabilir. Bunların yanı sıra özel bankalarda çalışanların işten çıkarılması durumunda kamu bankalarına nazaran sektörde daha çabuk ve kolay iş bulabilmesinin bilinirliği, diğer bankalara yüksek ücretlerle transferlerinin mümkün olması, çalışanın kendileriyle ilgili özel ve anlamlı günlerinde hatırlanıyor olması, ceza mekanizmasının yanı sıra ödül mekanizmasının da hissedilir derecede olması ve daha objektif performans sisteminin olması sayılabilir (Islam ve Saha, 2010; Meena ve Dangayach, 2012; Soysal ve Tan, 2013).

Mevduat bankalarında çalışanların iş tatmini katılım bankalarında çalışanların iş tatmininden düşük ve bunun sonucu olarak işten ayrılma niyetlerinin yüksek olmasının nedeninin çalışmamızda seçilen örneklemin bulunduğu şehir Konya'nın faizden uzak durma şeklindeki dini hassasiyet ve çevresel motivasyonun yüksek olması nedeniyle mevduat bankalarına nazaran daha fazla tercih edilmesi şeklinde yorumlamak 
mümkündür. Genel olarak mevduat bankalarına nazaran sayılarının bir hayli az olması ve bununla paralel olarak Konya ilinde bulunan şubelerinin az ve tercih edilirliğinin fazla olması, katılım bankalarında çalışanların hedeflerini daha kolay gerçekleştirebilmelerinin sonucu olarak baskının az olması, şube sayılarının gittikçe artacağı beklentisi ile yüksek ücretlerle transfer olma ihtimallerinin fazla olması da iş tatminlerinin yüksek ve işten ayrılma niyetlerinin düşük olması nedenleri arasında sayılabilmektedir. Özsoy vd. (2013) çalışmalarında benzer sonuçları bildirmişlerdir.

Bulgularda bankada 6-10 yıldır çalışanların, 0-5 yıldır çalışanlara göre işten ayrılma niyetlerinin daha yüksek olduğu tespit edilmiştir. Literatürde bulgumuzu destekleyen çalışmalar yer almaktadır (Eğinli, 2009; Crossman ve Abou-Zaki, 2003). İş yerinde çalışma süresi aynı zamanda o işle ilgili bilgi ve tecrübenin daha fazla olacağı anlamına geldiğinden ve bu gruptaki çalışanların kamuda iş bulabilme konusunda sahip oldukları akademik bilgilerinin kendilerinden daha uzun süreli çalışanlara göre daha taze ve kendilerine duydukları güven de haliyle fazla olduğundan işten ayrılma niyetleri de fazla olacaktır. İşe yeni başlayan 0-5 yıllık çalışanlar ise iş tecrübelerinin ve sahip oldukları müşteri portföylerinin az olması nedeniyle başka bankalar tarafından tercih edilebilirliklerinin fazla olamamasından kaynaklı olarak işten ayrılma niyetleri az olacaktır. Ayrıca bu grupta yer alan çalışanların işlerinden beklentilerinin daha yüksek olması ve mevcut işlerinde bir anda yükselebilme hırsları da işlerine sıkı sıkı bağlanmalarına, iş tatminlerinin fazla ve işten ayrılma niyetlerinin az olmasına neden olacaktır.

Müdür/müdür yardımcısı pozisyonunda çalışanların iş tatmini, personel pozisyonunda çalışanların iş tatmininden yüksek çıkmasının nedenleri arasında ücrete ek olarak almış oldukları prim, temettü, temsil ağırlama, kiralık otomobil gibi maddi kazanımlar ile saygı, statü, itibar, karar verme yetkisi gibi manevi kazanımlar sayılabilir.

Çalışmamızın kaygı kısmı ile ilgili bulguları inceleyerek mevcut literatür verileriyle bu hipotezleri ele alalım. Öncelikle demografik değişkenlerden kadınların ve bekarların sürekli kaygı puan ortalamalarının erkek ve evlilerin sürekli kaygı puan ortalamalarından anlamlı şekilde yüksek olduğu görülmüştür. Aslında bu genel olarak kaygı bozukluklarının kadınlarda ve bekarlarda daha yüksek olması verisiyle uyumludur (Wittchen, 2002; Öyekçin, 2008). Bunun nedenlerini biyolojik kuramcılar kadınlardaki fizyolojik yapı (kadınlara özgü hormonlar vb.) ile açıklarken evrimsel psikiyatristler türün devamında kadın cinsiyetin rolünün büyük olması nedeniyle dış dünyadan gelecek tehlikelere karşı daha duyarlı olmaları ile ilişkilendirmişlerdir (Doksat ve Savrun, 2001).

Ö. K. Ak, A. Diken, “iş Tatmini ve Kaygı Düzeyinin İşten Ayrıma Niyeti Üzerine Etkisi: Banka Çalışanları Üzerine Ampirik Bir Araştırma”, BDDK Bankacilık ve Finansal Piyasalar Dergisi, 14, (2), 2020, 175-204 
Mesleğini isteyerek seçenlerin durumluk ve sürekli kaygı puan ortalamalarının mesleğini isteyerek seçmeyenlerin kaygı puan ortalamalarından anlamlı şekilde düşük olduğu görülmüştür. Bu veri aslında beklenen bir sonucu yansıtmakta ve insanın istediği, kendini güvende hissettiği bir ortamda kaygının daha düşük olması ile açıklanabilir. Sonuçta iş tatmini bu kişilerde daha yüksek ve işten ayrılma puanları da daha düşük bulunmuştur. Bu da kaygı etkenlerinin az olduğu ve pozitif duyguların iş yerinde daha çok yaşandığını göstermektedir.

Çalışılan banka özelliklerine göre bakıldığında kamu bankasında çalışanların durumluk ve sürekli kaygı puan ortalamalarının özel bankada çalışanların kaygı puanlarından anlamlı şekilde yüksek olduğu tespit edilmiştir. Yine mevduat bankasında çalışanların durumluk ve sürekli kaygı puan ortalamalarının katılım bankasında çalışanların kaygı puanlarından anlamlı olarak yüksek olduğu görülmüştür. Buna paralel olarak da özel bankada çalışanlarda işten ayrılma niyeti kamu bankalarına göre düşük, iş tatmini daha yüksek bulunmuştur. Aynı karşılaştırma mevduat-katıım karşılaştırmasında mevduat bankaları lehinedir. Bu veriler, hissedilen iş tatminlerinin yüksekliği, işten ayrılma niyeti ile kaygı düzeyleri arasında ilişkiyi göstermiştir. Buradaki fark, özel bankada çalışanlara sunulan iş yeri ortamı, maddi kazanımlar, iş sonucu takdir edilme gibi etkenlerle kamu bankalarına göre avantajlı olabilmesi ile açıklanabilir. Ancak diğer açıdan özellikle sürekli kaygısı yüksek olanların yani stresi tolere etme yetisi düşük ve dış etkenlere karşı daha kolay kaygı tepkisi verenlerin bankacılık sektöründe iş devamlılığı açısından kamuyu daha güvenli bulduğu için baştan kamu bankalarını tercih etmesi etken olabilir. Sürekli kaygısı düşük olanlarda stresi tolere etme yetisi daha yüksek olduğu için özel bankalarda çalışmayı diğerleri gibi riskli bulmayıp buranın avantajlarına yoğunlaşarak özel bankaları tercih etmiş olabilirler. Katılım bankasında çalışanlarda ise farkın daha çok işin niteliği gereği hedef baskısının daha düşük olması, seçilen örneklemin bulunduğu şehir açısından değerlendirildiğinde mevduat açısından tercih edilirliği gibi işe ait özellikler bu sonuçla daha ilintili olabileceği düşünülmüştür. Tüm bu sonuçlar her ne kadar birçok faktör etkili olsa da bankaların personel alımı sürecinde özellikle sürekli kaygısı yüksek olmayan bireyleri tercih etmesinin, iş tatminin daha yüksek olarak iş devir oranını düşürmeye yol açma olasılığı olduğunu düşündürtmüştür. İşin niteliğine bağlı kaygı etkenlerini azaltmak ve özellikle kişiliğin bir parçası olan sürekli kaygısı yüksek olan bireylere yönelik kontrolü, stresle başa çıkma ve gevşeme teknikleri gibi bir takım önleyici beceriler geliştirmek işverenler için alınacak tedbirler arasında sayılabilir.

Kaygı, iş tatmini ve işten ayrılma ilişkisini irdeleyen analizlerin sonucuna bakıldığında durumluk kaygı, iş tatmini ile negatif yönlü, işten ayrılma niyeti ile ise pozitif yönlü orta düzeyde ilişkili bulunmuştur. Benzer şekilde sürekli kaygı da iş tatmini ile negatif 
yönde orta düzeyde ve işten ayrılma niyeti ile de pozitif yönlü orta düzeyde ilişkili olarak bulunmuştur. İ̧̧ tatmini ise işten ayrılma niyeti ile negatif yönlü orta düzeyde ilişkili olarak hesaplanmıştır. Analizler sonucunda durumluk ve sürekli kaygının iş tatminini ve işten ayrılma niyetini yordadığı görülmektedir. Sopiah ve Sangadji (2020) ve Yukongdi ve Shrestha (2020) yaptıkları araştırmalarda iş stresinin iş tatmini düşürdüğünü ve işten ayrılmaları artırdığını rapor etmiştir. Nitekim analizlerlerimiz sonucu daha çok kaygının iş tatminini düşürerek işten ayrılma niyetini artırdığı görülmüştür. Bu bulgular literatürde yapılmış diğer çalışmalar ile de uyumludur (Canbaz, 2001; Yazıcıoğlu ve Kızanlıklı, 2018 ve Srivastava ve Sinha, 1972, Akhtar vd. (2018).

Sürekli ve şiddetli kaygı, insanların kendilerini yorgun hissetmelerine, fiziksel ve ruhsal olarak başka hastalıklara da yakalanmasına neden olur. Stres yükü farklı olsa da her işin kendine has zorlayıcı yanları mutlaka olacaktır. Ancak aynı strese her kişi aynı tepkiyi vermemektedir. Ruhsal yapının geliştirdiği savunmaların olgunluğu, ruhsal yapının dayanıklılığı etkilenme derecesini belirlemede önemli olmaktadır. Sürekli kaygı düzeyi yüksek olanların kişilik özellikleri olarak stresi tolere etme becerileri daha düşük olduğundan dışsal uyaranlarla oluşan durumluk kaygısı da yüksek olmaktadır. İş yerindeki stresler veya algılanan olumsuzluklar kişide kaygı döngüsünü harekete geçirerek iş tatminini düşürebilir ve bu da işten ayrılma niyetini artırabilir.

Çalışma sonucunda bireyin durumluluk ve sürekli kaygı düzeyinin iş tatminini azaltan ve işten ayrılma niyetini artıran bir etken olması nedeniyle; personele yönelik kaygı ile baş etme eğitimlerinin verilmesi, öznel (personeli olumsuz etkileyebilecek yönetici tutumları) ve yapısal(çalışma ortamı dizaynı, renk vb.) kaygıyı artırabilecek durumlara yönelik tedbir alınması önerilir. Bireylerin mesai süresi içinde kaygıyı azaltacak etkin molalar vermesi (müzik dinletisi, kısa yoga, oyunlar, egzersiz vb.) sağlanabilir. Kişilik özelliği olarak kabul edilen yüksek sürekli kaygı düzeyine sahip bireyler tespit edilerek bunlara yönelik iş dağılımı, izin aralıkları, güdüleme yöntemleri gibi etkenler olumlu katkı sağlayacak şekilde düzenlenebilir. Nispeten iş tatmini düşük bulunan kamu bankalarında iş tatmininin arttırılması için hiyerarşik prosedür azaltılabilir, özerklik arttırılabilir ve çalışanın manevi tatminini arttıracak ögelere (doğumgünü, yılbaşı, bayram günlerinde küçük hediyeler vermek, performans ödülü olarak tatile göndermek vb.) ağırlık verilebilir.

Ö. K. Ak, A. Diken, "iş Tatmini ve Kaygı Düzeyinin Işten Ayrılma Niyeti Üzerine Etkisi: Banka Çalışanları Üzerine Ampirik Bir Araştırma", BDDK Bankacılık ve Finansal Piyasalar Dergisi, 14, (2), 2020, 175-204 


\section{Kaynakça}

1. Akhtar, A., Naheed, K., Akhtar, S. Ve Farooq, U. (2018). Impact of Job Stress on Employees'Job Satisfaction: An Empirical Study of Private Banksof Pakistan, Pakistan Journal of Social Sciences (PJSS), Vol. 38 (1), 137-151.

2. Akyüz, K. C.ve diğerleri (2011). Çalışanların İş Tatmin Düzeylerinin İncelenmesi (Muğla Orman Bölge Müdürlüğü Örneği), SDÜ Orman Fakültesi Dergisi, 12: $20-26$.

3. Al-Mashaan, O. S. (2003). Associations Among Job Satisfaction, Optimism, Pessimism, And Psychosomatic Symptoms For Employees In The Government Sector In Kuwait, Psychological Reports, 93, 17-25.

4. Altay, M. (2018). Çalışma Yaşam Kalitesinin İş Tatmini, Örgütsel Bağlıık ve Iş̧ten Ayrılma Niyeti ile Ilişkisinde İ̧ Yükü ve Lider- Üye Etkileşiminin Rol, Doktora Tezi, Süleyman Demirel Üniversitesi, Sosyal Bilimler Enstitüsü.

5. Baycan, A. (1985). An Analysis of Several Aspects of Job Satisfaction Between Diffrent Occupational Groups, Boğaziçi Üniversitesi, Yayınlanmamış Yüksek Lisans Tezi, i̇stanbul.

6. Byrd, T. G. ve diğerleri (2000). Behind Bars: An Assessment Of The Effects Of Job Satisfaction, Job-Related Stress, And Anxiety On Jail Employees' Inclinations To Quit, Journal of Crime and Justice, 23:2, 69-93.

7. Canbaz, S. (2001). Samsun Çıraklık Eğitim Merkezi'ne Devam Eden Çırakların Sosyo- demografik, Çalışma Yaşamı Özelliklerinin ve Durumluk-Sürekli Kaygı Düzeylerinin Değerlendirilmesi, Yayınlanmamış Yüksek Lisans Tezi, 19 Mayıs Üniversitesi Tıp Fakültesi, Halk Sağlığı Anabilim Dalı, Samsun.

8. Crossman, A. ve Bassem A. Z. (2003). Job Satisfaction And Employee Performance Of Lebanese Banking Staff, Journal of Managerial Psychology, Vol. 18, Issue: 4, 368-376.

9. Çarıkçı, İ. H. (2004). Hizmet İşletmelerinde Çalışan Kamu ve Özel Sektör Personelinin İş Tatmininin Karşılaştııılması, Amme İdaresi Dergisi, 37(4), 83-95.

10. Çelen, A. E., Sökmen, A. ve Bıyık, Y. (2015). Örgütlerde Yeniden Yapılanma Sürecinin İ̧̧ Tatmini ve Işsten Ayrılma Niyeti Üzerine Etkisi: Bir Banka Araştırması, Gazi Üniversitesi İktisadi ve İdari Bilimler Dergisi, Cilt 17, Sayı 3, 
30-50.

11. Dawley, D., Houghton J. D. ve Bucklew N. S. (2010). Perceived Organizational Support and Turnover Intention: The Mediating Effects of Personal Sacrifice and Job Fit, The Journal of Social Psychology, 150 (3), 238-257.

12. Doksat, M. K. ve Savrun M. (2001). Evrimsel Psikiyatriye Giriş. Yeni Symposium, 39 (3): 131-150.

13. Eğinli, A. T. (2009). Çalışanlarda İş Doyumu: Kamu Ve Özel Sektör Çalışanlarının İş Doyumuna Yönelik Bir Araştırma, Atatürk Üniversitesi İktisadi ve İdari Bilimler Dergisi, Cilt: 23, Sayı: 3, 35-52.

14. Eren, E. (2001). Örgütsel Davranış ve Yönetim Psikolojisi. 7. Baskı, İstanbul: Beta Basım Yayım.

15. Gökdeniz, İ. ve Merdan E. (2016). Meslek Seçimi ile İş Tatmini Iliş̧kisi: Bankaclık Sektöründe Bir Uygulama, Aksaray Üniversitesi İktisadi ve İdari Bilimler Fakültesi Dergisi, 8 (2), 111-121.

16. Groot, W. ve Van Den Brink, H. M. (1999). Job Satisfaction of Older Workers, International Journal of Manpower, Vol. 20, No.6, 343-360.

17. Güney, S. (2007). Yönetim ve Organizasyon. 2. Baskı, Ankara: Nobel Yayın Dağıtım.

18. Hulın, C. L. ve Smith, P. C. (1964). Sex Differences in Job Satisfaction, Journal of Applied Psychology, 48(2), 88-92.

19. Imran, H. A. ve diğerleri (2010). Factors Affecting Job Satisfaction of Employees in Pakistani Banking Sector, Online at http://mpra.ub.uni-muenchen. de/32130/ MPRA Paper No. 32130, posted 28. July 2011 01:15 UTC.

20. Islam, N. ve Saha, G. C. (2016). Job Satisfaction of Bank Officers in Bangladesh, papers.ssrn.com, https://ssrn.com/abstract=2856224.

21. Işık, E. (1996). Nevrozlar. 1. Baskı, Ankara: Baskı Kent Matbaa.

22. Jensen, J. M., Patel, P. C. ve Messersmith, J. G. (2013). High-Performance Work Systems And Job Control: Consequences For Anxiety, Role Overload, And Turnover Intentions, Journal of Management, 39(6), 1699-1724.

23. Kaya, F. ve Oğuzöncül, A. F. (2016). Birinci Basamak Sağlık Çalışanlarında İş 
Doyumu ve Etkileyen Faktörler, Dicle Tıp Dergisi, 43 (2), 248-255.

24. Kılıç, Y. (2017). Bankacılık Sektöründe Örgüt Kültürünün ve İnsan Kaynakları Uygulamalarının Mobbing Algısı ve İşten Ayrılma Niyeti Üzerindeki Etkisi, Yüksek Lisans Tezi, Nişantaşı Üniversitesi, Sosyal Bilimler Enstitüsü.

25. Koçak, O. ve Erdoğan, Z. B. (2011). Bankacılık Sektöründe Yeni İnsan Kaynakları Yönetimi Yaklaşımları Hakkında Bir Uygulama, Sosyal Siyaset Konferansları, 60, 259-283.

26. Kök, M. ve Çakıcı, A. (2016). Fabrika Çalışanlarının İ̧̧ Memnuniyetini Etkileyen Etmenler, İnsan \& Insan, Sayı 7, Kış 2016, 40-63.

27. Lambert, E. G., Hogan, N. L. and Barton, S.M. (2001). The Impact of Job Satisfaction on Turnover Intent: A Test of A Structural Measurement Model Using a National Sample of Workers, The Social Science Journal, 38, 233250.

28. Luthans, F. (2011). Organizational Behavior: An Evidence-Based Approach. 12th Edition, New York: Published By Mcgraw-Hill/Irwin.

29. Meena, M.L. ve Dangayach, G.S. (2012), Analaysis of Employee Satisfaction in Banking Sector, International Journal of Humanities and Applied Sciences, Vol 1, No 2, 78-81.

30. Mobley, W. H., Horner, S.O. ve Hollingsworth, A.T. (1978). An Evaluation Of Precursors of Hospital Employee Turnover, Journal of Applied Psychology, 63(4), 408-414.

31. Mobley, W. H. ve diğerleri (1979). "Review and Conceptual Analysis of the Employee Turnover Process", Psychological Bulletin, 86, 3, 493.

32. Noyes, R. ve Hoehn-Saric, R. (1998). Anksiyete Bozuklukları, 1. Baskı, İstanbul: Medikal\& Paramedikal Yayıncılık.

33. Okpara, J.O. (2006) The Relationship Of Personal Characteristics and Job Satisfaction: A Study of Nigerian Managers in The Oil Industry, The Journal of American Academy of Business, Vol 10, No 1.

34. Öner, N. ve Le Compte, A. (1985). Süreksiz Durumluk / Sürekli Kaygı Envanteri El Kitabı. 2.Baskı, İstanbul: Boğaziçi Üniversitesi Yayınları. 
35. Öner, N. ve Le Compte, A. (1998). Durumluk ve Sürekli Kaygı Ölçeği El Kitabı. 2. Baskı, İstanbul: Boğaziçi Üniversitesi Yayınları.

36. Örücü, E. ve Özafşarlıoğlu, S. (2013). Örgütsel Adaletin Çalışanların İşten Ayrılma Niyetine Etkisi: Güney Afrika Cumhuriyeti'nde Bir Uygulama, Mustafa Kemal Üniversitesi Sosyal Bilimler Enstitüsü Dergisi, 10(23), 335-358.

37. Öyekçin, D. G. (2008). Bir Devlet Hastanesi Psikiyatri Polikliniğine Bir Yıl Iç̧inde Basvuran Olguların Sosyo Demografik Özellikleri ve Psikiyatrik Tanı Dağılımı, Sivas Anadolu Psikiyatri Dergisi, Vol. 9, 1, 39-43.

38. Özsoy, İ., Görmez, B. ve Mekik, S. (2013). Türkiye'de Katılım Bankalarının Tercih Edilme Sebepleri: Ampirik Bir Tetkik, Yönetim ve Ekonomi Dergisi, Celal Bayar Üniversitesi I.İ.B.F., Cilt:20 Sayı:1, 187- 206.

39. Preacher, K. J. ve Hayes, A. F. (2004). SPSS And SAS Procedures For Estimating Indirect Effects In Simple Mediation Models, Behavior Research Methods, Instruments, \& Computers, 36(4), 717-731.

40. Preacher, K. J. ve Hayes, A. F. (2008). Asymptotic And Resampling Strategies For Assessing And Comparing Indirect Effects In Multiple Mediator Models, Behavior Research Methods, 40(3), 879-891.

41. Robie, C. ve diğerleri (1998). The Relation Between Job Level and Job Satisfaction, Group and Organization Management, (December), 470-495.

42. Sopiah ve Sangadji E. M. (2020). The Effect of Job Stress on Turnover Intention through Job Satisfaction of Government Commercial Bank Employees, International Conference on Islam, Economy, and Halal Industry Volume 2020, 66-82.

43. Soysal, A. ve Tan, M. (2013). İş Tatminini Etkileyen Faktörlerle Ilgili Hizmet Sektöründe Yapılan Bir Araştırma: Kilis Illi Kamu ve Özel Banka Personeli Örneği, Niğde Üniversitesi İiBF Dergisi, 2013, Cilt: 6, Sayı: 2, 45-63.

44. Spielberger, C. D., Gorsuch, R. L.ve Lushene, R. E. (1970). Manual For The State- Trait Anxiety Inventory. Consulting Psychologists Press, Palo Alto, CA.

45. Srivastava, A. K.ve Sinha, M. M. (1972). An Inquiry Into The Relationship Between Job Satisfaction And Job Anxiety, Journal of Indian Academy of Applied Psychology, 9(2), 39-44. 
46. Şimşek, S. ve Kara, H (2017). İş Tatmini - İ̧̧ Devri Niyeti Illişkisine Yönelik Bir Araştırma: Özel Güvenlik Sektörü Örneği,GÜSBEED, Gümüşhane Üniversitesi Sosyal Bilimler Enstitüsü Elektronik Dergisi,Cilt: 8, Sayı: 19, 85-101.

47. Tett, R. P. ve Meyer, J. P. (1993). Job Satisfaction, Organisational Commitment, Turnover Intention And Turnover: Path Analyses Based On Meta-Analytic Findings, Personnel Psychology, 46(2), 259-293.

48. Türkçapar, M. H. (2019). Fark Et, Düşün, Hisset, Yaşa, 1. Baskı, İstanbul: Epsilon Yayınları.

49. Weiss, D. J., Dawis, R. V. ve England, G. W. (1967). Manual For The Minnesota Satisfaction Questionnaire. In Minnesota Studies In Vocational Rehabilitation. Minneapolis, MN: University of Minnesota Press.

50. Wittchen, H. U. (2002). Generalized Anxiety Disorder: Prevalence, Burden And Cost To Society, Depression and Anxiety, 16:162-171.

51. Yavuz, A. ve Bedük, A. (2016). Örgütsel Sinizm ve Örgütsel Bağlılık Arasındaki İlişki: Bir Kamu Bankasının Konya Şubelerinde Örnek Uygulama, Selçuk Ün. Sos. Bil. Ens. Der. 2016; (35): 301-313.

52. Yazıcıoğlu, İ. ve Kızanlıklı, M. M. (2018). The Effects of Trait Anxiety on the Intention of Leaving and Burnout of Restaurant Employees, Turizm Akademik Dergisi, 1, 238-250.

53. Yukongdi, V. ve Shrestha, P. (2020). The Influence of Affective Commitment, Job Satisfaction and Job Stress on Turnover Intention: A Study of Nepalese Bank Employees, Review of Integrative Business and Economics Research, Vol. 9(1), 88-98. 